\title{
İşçi Sağlığı ve İş Güivenliği Araştırmalarında Psikolojinin Yeri: Türkçe ve İngilizce Alan Yazın Arasında Betimsel Bir Karşıllaştırma
}

\section{The Place of Psychology in the Area of Occupational Health and Safety: A Descriptive Comparison between the Turkish and Englih OHS Literatures}

\author{
Seydahmet $\operatorname{Ercan}^{1} \oplus$, Samet Çelik² ${ }^{\circledR}$
}

'Dr. Öğr. Üyesi, Zonguldak Bülent Ecevit Üniversitesi, Fen Edebiyat Fakültesi, Psikoloji Bölümü, Zonguldak, Türkiye ${ }^{2}$ Psikolog, Zonguldak Bülent Ecevit Üniversitesi, Sağlık Uygulama ve Araştırma Merkezi, Zonguldak, Türkiye

ORCID: S.E. 0000-0002-9174-9249; S.C.. 0000-0002-0578-3126

\footnotetext{
Sorumlu yazar/Corresponding author: Seydahmet Ercan,

Zonguldak Bülent Ecevit Üniversitesi, Fen Edebiyat Fakültesi, Psikoloji Bölümü, Zonguldak, Türkiye

E-posta/E-mail: seydahmetercan@gmail.com

Başvuru/Submitted: 06.02.2019

Kabul/Accepted: 10.10 .2020

Online Yayın/Published Online: 22.02.2021

Citation/Atıf: Ercan, S., \& Celik, S. (2021). İşçi sağlığı ve iş güvenliği araştırmalarında psikolojinin yeri: Türkçe ve İngilizce alan yazın arasında betimsel bir karşılaştırma. Psikoloji Çalışmaları - Studies in Psychology, 41(1): 111-141.

https://doi.org/10.26650/SP2020-0107
}

ÖZ

Uluslararası Çalışma Örgütü'nün verilerini ve şahit olduğumuz Soma maden kazası gibi birçok trajik iş kazasını dikkate aldığımızda, Türkiye'de işçi sağlığı ve güvenliği (ISSG) alanında hızlı bir iyileşme gerçekleştirmemiz gerektiği açıkça görülmektedir. Bu iyileştirmeyi gerçekleştirmek ilgili bütün tarafların (örn., Sosyal Güvenlik Kurumu, işveren örgütleri ve sendikalar) sorumluluğundadır ve ilgili taraflar öz eleştiride bulunarak neler yapmaları gerektiği konusunda öneriler geliştirmelidir. Bu noktada akademik camianın güncel, teorik ve uygulanabilir bilgi üreterek İSG'ye ilişkin arzulanan iyileşmelere katkı sunması gerekmektedir. Akademik camianın katkısını değerlendirmek amacıyla ilk olarak Türkçe İSG alan yazını nicel ve nitel olarak incelenmiştir. İkinci olarak, en çok atıf alan Türkçe ve İngilizce makaleler arasında karşılaştırma yapılarak Türkçe ve İngilizce alan yazındaki temel farkları ortaya koymak amaçlanmıştır. Türkçe alan yazına ilişkin yapılan analiz sonucunda İSG alanında Türkçe yazılan makalelerin yetersiz sayıda olduğu, sosyal ve davranış bilimi alanlarında çalışan araştırmacıların bu alana katkısının sınırlı düzeyde kaldığı, güvenlik iklimi ve güvenlik kültürü gibi önemli değişkenlerin yeterince incelenmediği, daha çok betimleyici araştırma yönteminin kullanıldığı ve hipotez testi sayısının düşük olduğu gözlemlenmiştir. En çok atıf alan Türkçe ve İngilizce makaleler arasında yapılan karşılaştırma sonucunda birinci yazar olarak Türkçe makalelerde en fazla mühendislik, İngilizce makalelerde ise en fazla psikoloji alanında çalışan araştırmacı sayısının olduğu; İngilizce makalelerin daha yüksek oranda hipotez testi içerdiği; Türkçe makalelerde en çok betimleyici, İngilizce makalelerde en çok tahminsel analiz yapıldığı ve son olarak İngilizce makalelerde yordayıcı değişken olarak en çok güvenlik iklimi, sonuç değişken olarak ise sağlık/iyi oluş ve kaza/yaralanma değişkenleri üzerinde durulduğu bulunmuştur. Bu bulgular ışığında Türkçe İSG alan yazınına katkı sunmak isteyen araştırmacıların İSG ile doğrudan ilişkili değişkenlerin üzerinde daha fazla durması, tahminsel analizlere yönelerek uygulanabilir bilgi üretmesi ve İSG konusuna farklı bilimsel alanların bakış açısı1 1şığında bütüncül bir şekilde yaklaşması gerekmektedir. Bu noktalarda psikoloji biliminin katkısının vazgeçilmez olacağı düşünülmektedir.

Anahtar Kelimeler: İş sağlı̆ı ve güvenliği, psikoloji, Türkçe alan yazın, iş güvenliği, işçi sağlığı, işçi sağlığı ve güvenliği 


\section{ABSTRACT}

It is evident that we need to achieve immediate improvements in occupational health and safety (OHS) in Turkey considering the statistics provided by the International Labor Organization and the numerous tragic work-accidents (e.g., Soma mining accident). All concerned parties such as the Social Security Institution and employers' associations need to fulfill their responsibilities by engaging in self-criticism. They must likewise develop suggestions to achieve such immediate improvements. Therefore, the academic society should contribute to the desired improvements in OHS by producing up-to-date, theoretical, and applicable knowledge. First, the Turkish OHS literature was examined to evaluate the academic society's contribution. Second, the most frequently cited Turkish and English OHS articles were compared to highlight the main differences in Turkish and English OHS literature. Upon analyzing the Turkish OHS literature, the results indicated that the number of Turkish OHS related articles was inadequate. Moreover, the contributions of social and behavioral scientists to this domain was not sufficient. Furthermore, important OHS variables such as safety climate and safety culture were not studied enough, studies mostly used descriptive analysis, and there was a lack of hypothesis testing. Comparing Turkish and English OHS articles, the results indicated that the first authors of the English articles were mostly psychologists and the first authors of the Turkish articles were mostly engineers. Moreover, the English articles included more hypothesis testing. The Turkish articles included mostly descriptive analyses, while the English articles included mostly predictive analyses. The English articles likewise mostly included the safety climate as a predictive variable and health and wellbeing and injury and accidents as criterion variables. Based on these findings, Turkish researchers who study OHS should focus on studying variables directly related to safety behavior and safety intensions. They should produce applied knowledge by conducting predictive rather than descriptive analyses. Also, they need to consider taking a holistic perspective by incorporating the results obtained by different scientific areas of study. Following these suggestions, a more profound contribution of psychology to OHS literature is required.
\end{abstract}

Keywords: Occupational health and safety, psychology, Turkish literature, occupational safety, worker health, worker health and safety

\title{
EXTENDED ABSTRACT
}

Considering the recent statistics by the International Labor Organization (ILO, 2017) and the previous statistics by other organizations (see Ceylan, 2011), there is a high number of work-accident-related deaths and at times, the failure to record and report non-fatal work injuries. These are two important signs, among many, suggesting the need of an immediate improvement in occupational health and safety (OHS) related policies and practices in Turkey. To achieve this, all the concerned stakeholders such as the Social Security Institution, the Ministry of Family, Labor and Social Services, labor unions, managers, employees, and academicians need to professionally undertake their duties. The academic society is responsible for providing policy makers and practitioners with up-to-date theoretical and applied knowledge about OHS as one of the concerned stakeholders. However, a quick research will show that Turkish academicians are not fulfilling this responsibility in a meaningful way. Alongside with this, there is already an urgent need to increase the quantity and quality of studies on OHS in Turkey. As such, we engaged in self-criticism as members of the academic society and tried to achieve three interrelated goals: (1) assessing the quantity and quality of contributions made by Turkish academicians in the area of OHS; (2) calling into attention the deficiencies observed in Turkish OHS literature; and (3) providing suggestions 
to eliminate the deficiencies observed. Furthermore, we made a comparison between the English and Turkish OHS literature by reviewing the most frequently cited articles in each literature.

\section{Method}

We reviewed articles written in Turkish that were published in an academic journal between 2000 and 2019. We identified 583 articles and coded them based on the coding sheet developed by the first author. Moreover, we identified the most frequently cited 101 articles per literature to make a comparison between the English and Turkish OHS literatures. The first author then coded these articles and the second author checked the first author's coding.

\section{Results}

Looking into the Turkish OHS articles, the academic backgrounds of the first authors were mostly in the areas of medicine, economics and management, engineering, OHS, and health sciences. There was only one first author with a background in psychology. Additionally, studies on OHS mainly focused on health, mining, construction, and production industries. Furthermore, most of the studies (32\%) used descriptive analysis. Only $16(3 \%)$ studies included a hypothesis test. The studies mostly used demographic variables and work-related factors (e.g., work settings) as predictors. Accidents, occupational diseases, physical health, and job attitudes were used as criteria.

It was found that 46 of these most frequently cited articles in English used a hypothesis testing after comparing the Turkish and English OHS literature. The corresponding number was only two for the most frequently cited articles in Turkish. Twenty-three of the first authors had an Engineering academic background (e.g., Şen \& Çınar, 2017), 21 in economics and management (e.g., Kılkış, 2013), and 11 in medicine (e.g., Türkkan, 2009). No author had a background in psychology. On the other hand, looking into the first authors of the most frequently cited studies in English, 47 of them had their academic background in psychology (e.g., Neal \& Griffin, 2006), 13 in business and economics (e.g., Nahrgang \& Morgeson, 2011), 12 in engineering (e.g., Mohamed, 2002), and nine in medicine (e.g., Costa, 2003). These results suggested that, contrary to the Turkish OHS literature, the English OHS literature has been highly benefiting from the perspective of psychology. The results further indicated that articles in English mostly included predictive analysis (e.g., Dollard \& Bakker, 2010). On the other hand, articles in Turkish mostly included descriptive analysis (e.g., Öz, 2005). 


\section{Discussion}

Our review clearly indicates that the Turkish literature on OHS needs immediate improvements. To achieve this goal of creating immediate improvements, the researchers and academicians need to: (1) focus on the variables directly related to safety behavior and safety intensions; (2) produce applied knowledge by conducting predictive, rather than descriptive analyses; and (3) take a holistic perspective by incorporating the results communicated by different scientific areas of study.

First, studies in the Turkish OHS literature must not focus on distal demographic variables (e.g., gender, age, and education). Rather, they must focus on proximal variables (e.g. safety climate, safety culture, and leadership) directly related to various work safety criteria (Burke \& Signal, 2010; Christian, Bradley, Wallace, \& Burke, 2009).

Second, Turkish OHS literature lacks studies which use hypothesis testing. We know that hypothesis testing is one of the best tools to acquire conceptual and procedural knowledge in an integrated manner (Howe, Tolmie, Duchak-Tanner, \& Rattray, 2000). Therefore, the Turkish OHS literature should focus more on developing and testing scientific hypotheses.

Finally, more Turkish behavioral scientists (particularly psychologists) should focus their attention on the subject of OHS. Ensuring that employees are engaging in safe behaviors is one of the essential requirements of achieving higher levels of OHS. Psychologists will provide us with valuable insights to better understand factors affecting employees' safety intentions and actions. This is because they have the expertise in the area of studying human behavior and cognition. 
Uluslararası Çalışma Örgütü (2017) dünya genelinde her yıl yaklaşık olarak 2,7 milyondan fazla ölümcül ve 374 milyona yakın yaralanmaya neden olan iş kazası yaşand1ğını tahmin etmektedir. Özellikle gelişmemiş ve gelişmekte olan ülkelerden sağlıklı veri elde etmenin zorluğu nedeniyle gerçek rakamların bilinenin üstünde olabileceği düşünülmektedir (Hämäläinen, Takala ve Saarela, 2006). Her ne kadar bu rakamlar kesin olmasa da işçi sağlığ1 ve güvenliği (ISSG) konusunun öneminin ve iş kazalarının ne derece büyük bir sorun olarak durmaya devam ettiğinin kavranması açısından, bu tahmini rakamlar önemlilik göstermektedir. Ülkemizdeki durum da dünya geneliyle paralellik göstermektedir. Türkiye'de İSG konusunda hangi aşamada olduğumuzu belirtmek adına örnek vermek gerekirse, Kozlu ve Soma'da meydana gelen maden kazalarına ve yakın zamanlarda inşaat şantiyelerinde meydana gelen kazalara değinebilir. Zonguldak'ın Kozlu ilçesinde 3 Mart 1992 tarihinde meydana gelen iş kazası sonucu 263 madenci hayatını yitirmiş ve 550 madenci yaralanmıştır. Manisa'nın Soma ilçesinde 13 Mayıs 2014 tarihinde meydana gelen iş kazası sonucu 301 madencimiz hayatını kaybetmiştir (Yaşar, İnal, Yaşar ve Kaya, 2015). İnşaat sektörüne bakıldığında, İstanbul'un Esenyurt ilçesinde 11 Mart 2012 tarihinde bir inşaat firmasına ait şantiyede çıkan yangın sonucu 11 işçi (Anadolu Ajansı, 2012), İstanbul'un Şişli ilçesinde 6 Eylül 2014 tarihinde asansörün yere çakılması sonucu 10 işçi hayatını kaybetmiştir (Anadolu Ajansı, 2014). Bu ve benzeri kazalar, Türkiye'deki durumun vahametini göstermekte ve İSG konusunda yapılacak iyileştirmelerin aciliyetine işaret etmektedir.

Bu şekilde yazılı ve görsel medyaya yansıyan iş kazaları ve işçi ölümleri buz dağının görünen kısmıdır. Yazılı ve görsel medyaya yansımayan ya da Sosyal Güvenlik Kurumu'na (SGK) raporlanmayan çok sayıdaki ölümcül olmayan iş kazaları İSG'ye ilişkin başka bir soruna işaret etmektedir (Yeşildal, 2005). Bu sorun, ülkemizde iş kazası raporlama kültürünün henüz yerleşmiş olmamasıdır. Bu sorunun büyüklüğü ILO’nun (2017) sigorta kayıtlarını dikkate alarak hazırladığı iş kazasına bağlı ölüm sayısı ve ölümcül olmayan kaza sayısı istatistiklerinde açıkça ortaya konmaktadır. ILO tarafından 20042011 arasındaki yıllara ilişkin istatistiklerde, Türkiye'de iş kazasına bağlı yıllık ortalama ölüm sayısı gelişmiş ülkelerin çok üstündeyken, yıllık ortalama ölümcül olmayan iş yaralanmaları sayısı gelişmiş ülkelerin çok altında kalmıştır (Uluslararası Çalışma Örgütü, 2017). Ölümlü iş kazalarının sigortaya bildirilmesi kaçınılmaz olduğu için bu istatistikte Türkiye gelişmiş ülkelerin önünde yer almaktadır. Ölümcül olmayan iş kazalarında ise çok ciddi yaralanmalar olmadığ 1 müddetçe kazaların raporlanması iş 
yeri yönetiminin inisiyatifine, iş yerindeki İSG kültürünün gelişmişliğine ve işçilerin İSG konusundaki bilinç düzeyine bağlı olarak değişmektedir (Clarke, 1998; Probst ve Estrada, 2010). İSG’ye ve güvenlik performansına ilişkin iyileşme sağlamak adına yanlışların ve hataların düzeltilebilmesi için ramak kala olayların bile raporlanıp incelenmesinin önem arz ettiği düşünüldüğünde (Jones, Kirchsteiger ve Bjerke, 1999; Sheikhtaheri, 2014) iş kazalarının doğru bir şekilde raporlanmaması, İSG kültürünün ülkemizdeki resmi ya da özel kurumlar tarafından henüz içselleştirilmediği olasılığını güçlendirmektedir.

Bu çalışmanın genel amacı, akademik camianın eleştirisini yaparak, akademinin İSG konusundaki bilgi ve birikimin artmasına yönelik katkısını nicel ve nitel olarak değerlendirmektir. Değerlendirme sonucunda belirlenen eksikliklere dikkat çekmek ve bu eksikliklerin giderilmesi için yapılması gereken uygulamalar hakkında görüş beyan etmek ise çalışmanın diğer amaçlarındandır. Bu amaçlar doğrultusunda, ilk olarak İSG alan yazını gözden geçirilerek İSG nedir, neleri kapsar ve neden önemlidir soruları cevaplanmaya çalışılacaktır. Daha sonra İSG konusunda yayınlanan Türkçe akademik makaleler önceden belirlenen kriterler ışığında değerlendirilecek ve son olarak yıllık ortalama en fazla sayıda atıf almış 101 Türkçe ve 101 İngilizce makale nitelik bakımından karşılaştır1lıp, Türkçe ve İngilizce alan yazın arasındaki temel farklara değinilecektir. Bu karş1laştırmanın, Türkçe alan yazındaki eksikliklerin daha objektif bir şekilde değerlendirilmesini sağlayacağ düşünülmektedir.

\section{İşçi Sağlığı ve Güvenliği: Nedir ve Neden Önemlidir?}

İSG'nin en geniş anlamıyla, çalışanların fiziksel ve/veya psikolojik rahatsızlık duymalarına neden olabilecek her türlü fiziksel (işin yapıldığı fiziki alana ve ekipmanlara ilişkin), sistemsel (iş yeri yönetim şekline ve politikalarına ilişkin) ve yöntemsel (işin yapılış yöntemine ilişkin) riskleri en az seviyeye indirmek için yapılan çalışmaların bütününü oluşturduğu söylenebilir. Bu doğrultuda İSG, çalışanların hem fiziksel hem de psikolojik açıdan sağlıklı ve huzurlu bir çalışma hayatları olmasını amaçlar (Danna ve Griffin, 1999). Her ne kadar İSG konusu ele alınırken yalnızca çalışanların değil, işletmelerin ve üretimin güvenliğinin de düşünülmesi gerekse de (Özkılıç, 2005), iş̧̧i sağl1ğına gelecek bazı zararların (ölüm ve sakatlanma gibi) telafisinin mümkün olmaması nedeniyle, işçi sağlı̆̆ının ve işçi güvenliğinin öncelikli olarak ele alınması gerektiği düşünülmektedir. Bu gereklilik İSG konusunda çalışan araştırmacıların ve bu konunun diğer taraflarının öncelikli olarak işçi güvenliği ve işçi sağlığ 1 konusuna eğilmelerinin önemine işaret etmektedir. 
Danna ve Griffin (1999) İSG'nin önemine işaret ederken üç farklı konuya dikkat çekmiştir. İlk olarak, iş yerinde tecrübe edilen olayların ya da durumların işçilerin hem iş yerindeki hem de iş yeri dışındaki yaşamlarını etkiliyor olmasına vurgu yapmışlardır. İşçilerin iş yerinde yaşadıkları fiziksel ya da psikolojik açıdan güvenliklerini veya sağlıklarını etkileyen negatif olayların etkisi iş yeri dışındaki günlük hayatlarına taşar (Bkz. Spillover Effect, Zedeck ve Mosier, 1990) ve günlük hayatlarındaki davranışlarını, tutumlarını ve yaşantılarını etkiler. Bu nedenle işçiler işyerinde kendilerini fiziksel ve psikolojik bakımdan güvende hissetmediklerinde ve sağlıksız şartlarda çalıştıklarında, bu durum kaçınılmaz olarak onların işyeri dışındaki bireysel ve sosyal hayatlarını olumsuz bir şekilde etkilemektedir.

Danna ve Griffin (1999) ikinci olarak, cinsel taciz (sexual harassment), ergonomi ve işyeri saldırganlığı (workplace aggression) gibi önemli görülen ve çalışanlar için risk oluşturan durumların doğrudan İSG ile bağlantılı olmasına vurgu yapmıştır. Son yıllarda cinsel taciz (örn., Gruber ve Morgan, 2005), ergonomi (örn., Dul ve Neumann, 2009) ve işyeri saldırganlığı (örn., Hershcovis ve ark., 2007) üzerine yapılan çalışmaların sayısı artmış ve bu değişkenler çoğunlukla İSG konusu etrafında tartışılmıştır (Weil, 2001). $\mathrm{Bu}$ durum, İSG'nin kapsamının diğer birçok önemli değişkeni de içine alacak şekilde geniş olduğuna işaret etmektedir. Bu doğrultuda İSG üzerine çalışan araştırmacıların bakış açılarını geniş tutmaları ve bu konuyu çok yönlü olarak ele almaları, ulaşacakları sonuçların doğruluğunu, geçerliliğini ve pratikte etkili bir şekilde uygulanabilirliğini artıracaktır.

Danna ve Griffin (1999) son olarak İSG'ye yeterli derecede önem vermemenin işçiler ve firmalar için oluşturduğu olası sonuçların vahametine vurgu yapmıştır. Öncelikle işe ilişkin riskler ve tehlikeler işçilerin tükenmişlik (burn-out) hissetmelerine yol açmaktadır (Nahrgang, Morgeson ve Hofmann, 2011). Ayrıca, iş yerinde sağlıksız şartlarda çalışan ve bundan dolayı sağlığı bozulan çalışanlar verimli çalışamazlar, işleriyle ilgili yerinde ve doğru karar vermekte zorlanırlar ve işten kaytarma eğiliminde olabilirler (Boyd, 1997). İş kazaları ve yaralanmaları şirketleri de birçok açıdan olumsuz etkiler. Bu olumsuz etkiler iş zamanından kayıp, iş makinalarında ve malzemelerinde oluşan hasarlar, hukuk ve denetim hizmeti alımına ilişkin masraflar, ceza ödemesi ve iyileştirme uygulamalarına ilişkin masraflar olmak üzere dört ana başlık altında toplanabilir (Rikhardsson ve Impgaard, 2004). İş hastalıklarının ve kazalarının sebep olduğu istenmeyen sonuçlardan sadece çalışanlar ve firmalar muzdarip değillerdir. Weil (2001)'in 
belirttiği gibi iş kaynaklı hastalıklar ve kazalar sosyal güvenlik bağlamında devletlerin ekonomisine de büyük bir yük olarak yansımaktadır ve bu yük çoğu zaman resmi olarak hesap edilen değerin çok üstündedir. İş kaynaklı hastalıklar ve kazaların ayrıca işçi ve işveren ilişkilerine, aile dinamikleri üzerine ve bireylerin topluma katılımı ve akıl sağlıkları üzerine çoğu zaman göz ardı edilen fakat önemli etkileri vardır (Dembe, 2001). Bu çalışmalardan da anlaşılacağı üzere, İSG'ye ilişkin uygulamalar ve sonuçlar her bir işçiyi bireysel olarak etkilediği gibi toplumun tamamını doğrudan ya da dolaylı olarak önemli ölçüde etkilemektedir. Bu doğrultuda İSG'ye ilişkin uygulamaları ve sonuçları bireyden topluma geniş bir yelpazede ele almak, İSG konusunu tam manasıyla kavramak için bir gereklilik arz etmektedir.

Bütün bunlardan daha önemli olan bir diğer durum ise her y1l iş kazaları sonucu 2.780.000'den fazla çalışanın hayatını kaybetmesidir (Uluslararası Çalışma Örgütü, 2017). Bu sayı, Uluslararası Yollarda Güvenli Seyahat Birliği (Association for Safe International Road Travel, ASIRT) verileri dikkate alındığında trafik kazaları sonucu hayatını kaybedenlerin sayısının iki katından daha fazladır (Association for Safe International Road Travel, 2017). İşyerleri etkili İSG uygulamaları yaparak iş kazasına bağlı ölümleri azaltıp her yıl milyonlarca işçinin hayatını kurtarabilirler. Sadece bu durum bile tek başına İSG konusuna gerekli önemin verilmesi için yeterli bir neden teşkil etmektedir.

\section{YÖNTEM}

\section{Türkçe Alan Yazın Taraması: İSG'nin Türkçe Alan Yazındaki Yeri}

İSG'nin Türkçe alan yazındaki yerini anlamak için ilk olarak bu konuda 2000 ve 2019 yılları arasında yayınlanan ve Google Scholar'dan erişilebilen tüm Türkçe makaleler belli kriterler doğrultusunda incelenmiştir. Bu inceleme, İSG konusunun Türkçe alan yazındaki yerinin genel manada anlaşılması açısından önem arz etmektedir. İkinci olarak, İSG konusunda yıllık ortalama en fazla atıf almış 101 Türkçe ve 101 İngilizce makale arasında bir karşılaştırma yapılmıştır. Bu karşılaştırmanın amacı ise, Türkçe alan yazının İngilizce alan yazından hangi özellikler bakımından farklılık gösterdiğini, gözlemlenen bu farklılıkların en aza indirilmesi için hangi adımların atılması gerektiğini bulmaktır. 


\section{Alan Yazın Tarama}

Türkçe alan yazın taranmaya başlamadan önce birinci yazar tarafindan makalelerin hangi özelliklerinin kodlanacağını gösteren bir kodlama tablosu oluşturulmuştur. $\mathrm{Bu}$ kodlama tablosu oluşturulmadan önce birinci yazar tarafindan Türkçe alan yazın genel olarak taranmış ve çalışmalara ilişkin hangi bilgilerin kodlanması gerektiği yönünde bir görüş geliştirilmeye çalışılmıştır. Bu ön araştırma sonucunda kalitatif bir alan yazın analizinin uygun olduğu görüşü ortaya çıkmış ve bu görüş doğrultusunda birinci yazar tarafından kodlama tablosu şekillendirilmiştir. Alan yazın analizine dahil edilen çalışmaların hangi özelliklerinin kodlandığına dair bilgi Tablo 1'de görülmektedir.

Tablo 1. Türkçe Yazın Taramasında Kullanılan Kodlama Tablosu

\begin{tabular}{|c|c|c|}
\hline Değişken & Kodlama işleminin içeriği & Kodlamaya ilişkin notlar \\
\hline Yll & Çalışmanın yayımlandığı yıl & \\
\hline Yazarlar & Çalışmanın yazarları & \\
\hline Yazar alanı & $\begin{array}{l}\text { Makalenin birincil yazarının en son eğitim aldığ } 1 \\
\text { akademik alan }\end{array}$ & $\begin{array}{l}\text { Bu değişken kodlanırken birinci } \\
\text { yazarın akademik alanı dikkate } \\
\text { alınmıştır. }\end{array}$ \\
\hline Yayın türü & $\begin{array}{l}\text { Yayının türü makale, kitap bölümü, konferans tebliği, } \\
\text { yüksek lisans tezi, doktora tezi, rapor ve uzmanlık } \\
\text { tezi olmak üzere kodlanmıştır. }\end{array}$ & $\begin{array}{l}\text { Çalışmaya sadece akademik } \\
\text { dergilerde yayınlanan makaleler } \\
\text { dahil edilmiştir. }\end{array}$ \\
\hline Sektör & $\begin{array}{c}\text { Yayına konu çalışmanın yapıldığı işletmenin içinde } \\
\text { bulunduğu sektör (Örn., inşaat, maden, orman, tarım } \\
\text { ve imalat) not edilmiştir. }\end{array}$ & \\
\hline $\begin{array}{l}\text { Yayında kullanılan } \\
\text { araştırma yöntemi }\end{array}$ & $\begin{array}{l}\text { Yayında kullanılan araştırma yöntemi kalitatif } \\
\text { (qualitative), kantitatif (quantitative), yasa tartışması, } \\
\text { görüş belirtme, anket geliştirme/uyarlama, arşiv veri } \\
\text { analizi, model/yöntem uygulama ve geliştirme ve } \\
\text { özel uygulama olarak kodlanmıştır. }\end{array}$ & $\begin{array}{l}\text { Kantitatif yayın yöntemi } \\
\text { betimleyici ve tahminsel olarak } \\
\text { iki ayrı şekilde kodlanmıştır. }\end{array}$ \\
\hline Hipotez testi & $\begin{array}{l}\text { Yapılan çalışmada bir hipotez geliştirilip test edilmiş } \\
\text { midir, bu bilgi kodlanmıştır. }\end{array}$ & \\
\hline Sonuç değişken & $\begin{array}{l}\text { Kantitatif çalışmalarda sonuç olarak hangi } \\
\text { değişkenlerin (Örn., kaza sayısı, güvenlik kültürü, } \\
\text { riskli temas, yaralanma sayısı ve hastalık) kullanıldığı } \\
\text { not edilmiştir. }\end{array}$ & \\
\hline Yordayıcı değişken & $\begin{array}{l}\text { Kantitatif çalışmalarda yordayıcı olarak hangi } \\
\text { değişkenlerin (Örn., İSG eğitimi, çalışma süresi, iş } \\
\text { yerinde hekim bulundurma ve çalışma koşulları) } \\
\text { kullanıldığı not edilmiştir. }\end{array}$ & \\
\hline Atıf & $\begin{array}{c}\text { Yapılan çalışmaya ne kadar atıf yapılmış not } \\
\text { edilmiştir. }\end{array}$ & $\begin{array}{l}\text { Atıf sayıları Google Scholar'da } \\
\text { belirtilen atıf sayılarıdır. }\end{array}$ \\
\hline
\end{tabular}

Kod tablosu oluşturulduktan sonra iş sağllğl ve güvenliği, iş̧̧i sağllğ ve güvenliğ $i$, iş güvenliği, iş̧̧i sağglı̆̆l, iş sağllğ l, çalışan sağllğl, çalışan güvenliği ve iş kazası anahtar kelimeleri kullanılarak Google Scholar üzerinden Türkçe çalışmalar taranmıştır. Görece 
daha güncel olan yayınlara odaklanmak için tarama sonucu ulaşılan yayınlardan sadece 2000-2019 yılları arasında yayımlanan ve konusu İSG olan akademik makaleler bu çalışmaya dahil edilmiştir. Bu kriterler 1şığında 583 çalışmaya ulaşılmıştır. Birinci yazar tarafından 2012 ve 2016 yılları arasındaki, 2018 ve 2019 yıllarında yayımlanan çalışmalar, ikinci yazar tarafindan ise 2017 y1lı içinde ve 2011 ve öncesi yıllarda yayımlanan çalışmalar kodlanmıştır. Daha sonra birinci yazar tarafından ikinci yazarın, ikinci yazar tarafından da birinci yazarın kodlamaları kontrol edilmiştir. Bu aşamada yazarlar arasından ortaya çıkan ve kodlamaların \%4,3 'lük kısmına denk gelen anlaşmazlıklar karşılıklı görüşülerek çözümlenmiş ve ortak bir karara varılmıştır.

İngilizce ve Türkçe alan yazın arasında bir karşılaştırma yapmak amacıyla yıl bazında ortalama en çok atıf alan 101 Türkçe ve 101 İngilizce makale taranmıştır. Yı1lık ortalama 1'den fazla atıf alan Türkçe makale sayısı 91, bir atıf alan makale sayısı ise 29 olarak bulunmuştur. Bu 29 makaleden karşılaştırmaya dahil edilecek makaleleri belirlemek için bu makaleler toplam atıf sayılarına göre yüksekten düşüğe sıralanmıştır. Bu sıralamaya göre altı ya da daha fazla atıf alan makale sayısı 6 , beş atıf alan makale sayıs1 ise 4 olarak bulunmuştur. Bu doğrultuda beş ya da daha fazla sayıda atıf alan makaleler karşılaştırmaya dahil edildiğinde karşılaştırmaya dahil edilecek Türkçe makale sayısı 101 olmuştur. Bu nedenle İngilizce makale sayısı da 101 olarak belirlenmiştir. 20002019 yılları arasında yayımlanan ve yıllık ortalama en çok atıf alan 101 İngilizce makaleye ulaşmak için Publish or Perish (Harzing, 2007) programından faydalanılmıştır. Publish or Perish programı Google Scholar veri tabanını kullanarak taranan çalışmaların atıf sayılarına göre sıralama yapma imkanı sunan bir programdır. Bu programda employee safety, employee health, employee health and safety, occupational safety, occupational health, occupational health and safety, work safety ve workplace safety anahtar kelimelerini kullanılarak tarama yapılmış ve çıkan sonuçlar yıllık ortalama atıf sayılarına göre sıralanmıştır. Daha sonra ilk yazar tarafından en çok atıf almış İngilizce makalelerin hangi yıla ait olduğu, hipotez testi içerip içermedikleri, kaç atıf aldıkları, çalışmaların birinci yazarının en son hangi akademik alanda eğitim aldığı, çalışmalarda hangi araştırma yönteminin kullanıldığı ve hangi değişkenler üzerinde durulduğu kodlanmıştır. Bu kodlamalar ikinci yazar tarafından kontrol edilmiştir. Kontrol sonrası kodlamaların \%1,6`lık kısmına denk gelen anlaşmazlıklar karşılıklı görüşülerek çözümlenmiş ve ortak bir karara varılmıştır. 
Hangi çalışmaların hipotez testi uyguladığı belirlenirken, istatistiksel olarak test edilen ilişkilere ya da farklara dair ilgili çalışmanın yöntem kısmından önceki bölümlerinde bir tartışma ortaya konulup konulmadığına dikkat edilmiştir. Örneğin İncesu ve Atasoy (2015), çalışan güvenliği hakkında eğitim almış olan hemşirelerin ve bu konuda eğitim almamış olan hemşirelerin çalışan sağlı̆̆1 ve güvenliği kültürü alt ölçek ortalamaları arasında fark olup olmadığını bulmak için t-testi uygulamıştır. Fakat çalışmanın giriş kısmında bu farklara ilişkin herhangi bir hipotez belirtmemiş ya da çalışan güvenliği hakkında eğitim almış hemşireler ile bu konuda eğitim almamış hemşireler arasında ilgili ölçeğin alt boyutları ortalamalarının neden farklı olabileceği konusunda herhangi bir tartışma ortaya koymamışlardır. Bilimsel çalışmalarda hipotezlerin veri toplamaya başlamadan önce oluşturulması ya da en azından araştırmacının çalışacağı değişkenler arasındaki ilişkilere ya da farklara dair bir öngörüsünün olması gerekmektedir. Araştırmacılar geliştirdikleri bu hipotezleri ya da ulaştıkları öngörüleri test etmek için veri toplayıp, topladıkları veriyi analiz etmelidirler. $\mathrm{Bu}$ doğrultuda, eğer makalede hipotezler açık bir şekilde yazılmamışsa ve de makalenin yöntem kısmından önceki bölümlerinde test edilen fark ya da ilişkilere dair herhangi bir tartışma ortaya koyulmamışsa bu makaleler de hipotez testi içermiyor olarak kodlanmıştır.

\section{Veri Analizi}

Microsoft Excel programına her makaleye ilişkin girilen veriler ilk olarak betimsel analiz yöntemlerinden sıklık dağılımı analizleri yapılarak incelenmiştir. Bu doğrultuda İSG konusunda yazılan Türkçe yayınların yıllara, ilk yazarlarının en son eğitim aldığ akademik alana, konu ettiği sektöre, hipotez testi içerip içermediğine ve aldığı atıf sayısına, ayrıca yayınlarda kullanılan araştırma yöntemine ve değişkenlere ilişkin sıklık analizi yapılmıştır. İkinci olarak ise seçilen 101 Türkçe ve 101 İngilizce yayın için hipotez testi içerip içermediklerine, ilk yazarlarının en son eğitim aldığı akademik alana ve ayrıca bu makalelerde kullanılan araştırma yöntemlerine ve değişkenlere ilişkin sıklık analizi yapılıp elde edilen sonuçlar kullanılarak çubuk grafikleri ve sıklık tabloları oluşturulmuştur. Son olarak yıllık ortalama en çok atıf alan Türkçe ve İngilizce makaleler arasındaki hipotez sayısına, ilk yazarın akademik alanına ve kullanılan yöntemlere ilişkin gözlemlenen farklılıkların istatistiksel olarak anlamlı olup olmadığını test etmek adına Ki-Kare bağımsızlık testleri uygulanmıştır. 


\section{BULGULAR}

\section{Türkçe Alan Yazınına İlişkin Genel Analiz Bulguları}

İlk olarak Türkçe alan yazında İSG konusunda yapılan yayınların yıllara göre dağıl1mı incelenmiştir. İSG alanında 2000-2019 yılları arasında yayınlanan Türkçe araştırmaların sayısının yıllara göre dağılımı Şekil 1'de gösterilmektedir. İSG konusunda yapılan Türkçe yayın sayısı 2000 ve 2013 yılları arasında çoğunlukla 10 ile 20 arasında dalgalanırken, 2014 yılında sayı 41'e, 2015 yılında ise 66'ya yükselmiştir. 2016 yılında yayımlanan makale sayısı bir önceki yıla oranla \%68,2'lik bir düşüş göstermiştir ve 21'e inmiştir. 2017 ve 2018 yıllarında ise yayın sayısında tekrar bir artış gözlenmiş ve sayı 2017 için 50’ye, 2018 için ise 74'e ulaşmıştır. 2019 yılındaki yayın sayısı ise bir önceki yılın yaklaşık iki katı artarak 140 ulaşmıştır.

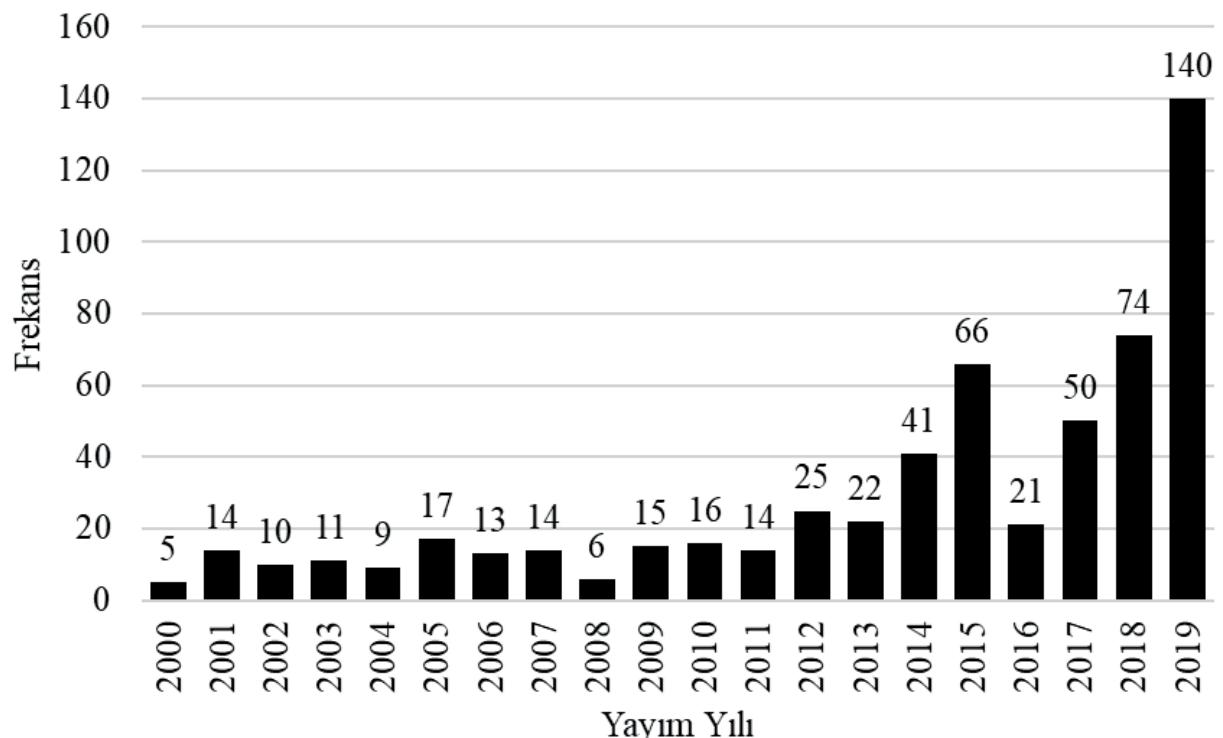

Şekil 1. İSG Konusunda 2000-2019 Yılları Arasında Akademik Dergilerde Yayınlanan Makalelerin Yıllara Göre Dağılımı.

İkinci olarak çalışmaya dahil edilen yayınların ilk yazarının en son eğitim aldığı akademik alan dağılımı incelenmiştir. Şekil 2'de bu sıklık analizinin sonuçları görülmektedir. Yayınların ilk yazarlarının akademik alanlarının dağılımı incelendiğinde mühendislik (\%24), tıp (\%18), çalışma ekonomisi/iktisat/işletme (\%13), İSG (\%10) ve sağlık bilimleri (\%5) alanında çalışan araştırmacıların İSG konusuna diğer alanlarda çalışan araştırmacılara oranla daha fazla yoğunlaştığı görülmektedir. Yapılan araştırmada birinci yazarının akademik alanı psikoloji olan sadece bir çalışmaya ulaşılmıştır. 


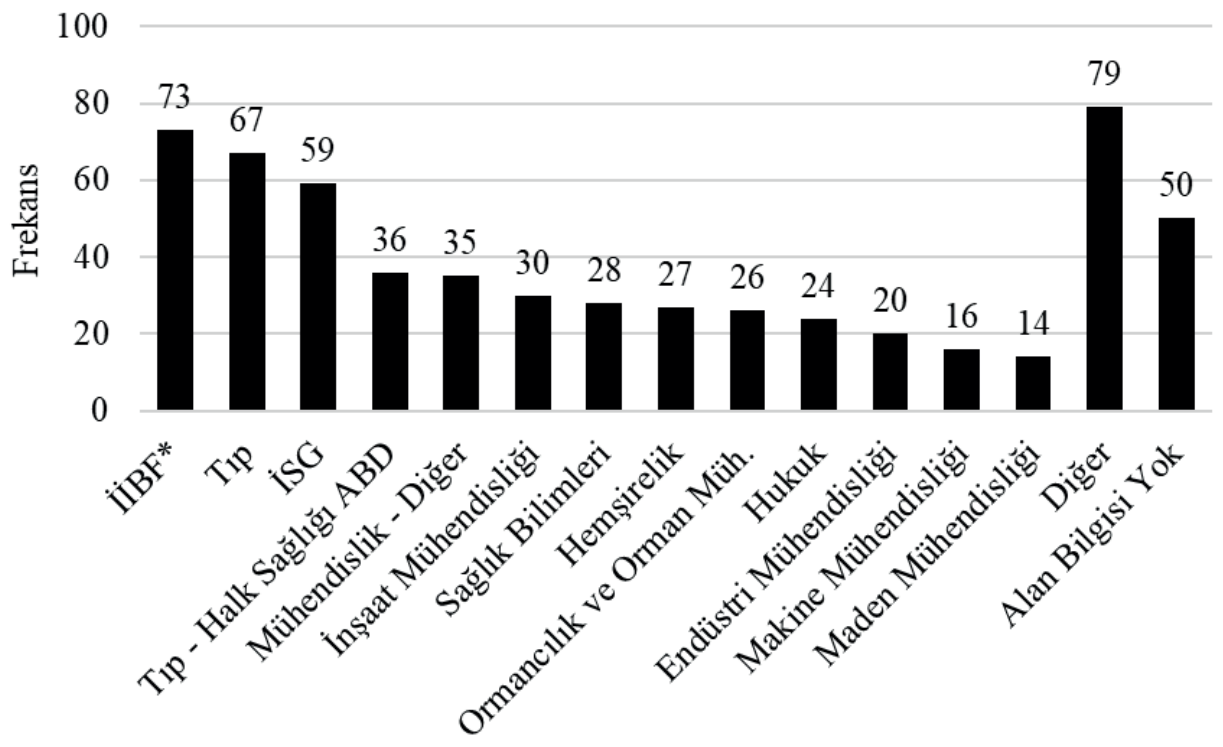

Birinci yazarın akademik alanı

Not. *iktisat, işletme ve çalışma ekonomisi ve endüstriyel ilişkiler İiBF olarak kodlanmıştır.

Şekil 2. İSG Konusunda 2000-2019 Yılları Arasında Akademik Dergilerde Yayınlanan Makalelerin Birinci Yazarlarının En Son Eğitim Aldığı Akademik Alanlarına Göre Dağılımı.

Üçüncü adım olarak yayınların konu ettiği sektörlerin dağılımı incelenmiştir. Şekil 3’te yapılan çalışmaların sektörlere göre dağılımını verilmektedir. Beklendiği gibi İSG alanında yapılan çalışmalar daha çok sağlık (\%20), madencilik (\%14), inşaat (\%12) ve üretim sektörleri (\%12) gibi işçi sağlığı ve güvenliği riskinin göreceli olarak yüksek olduğu sektörlerde yoğunluk kazanmıştır. 


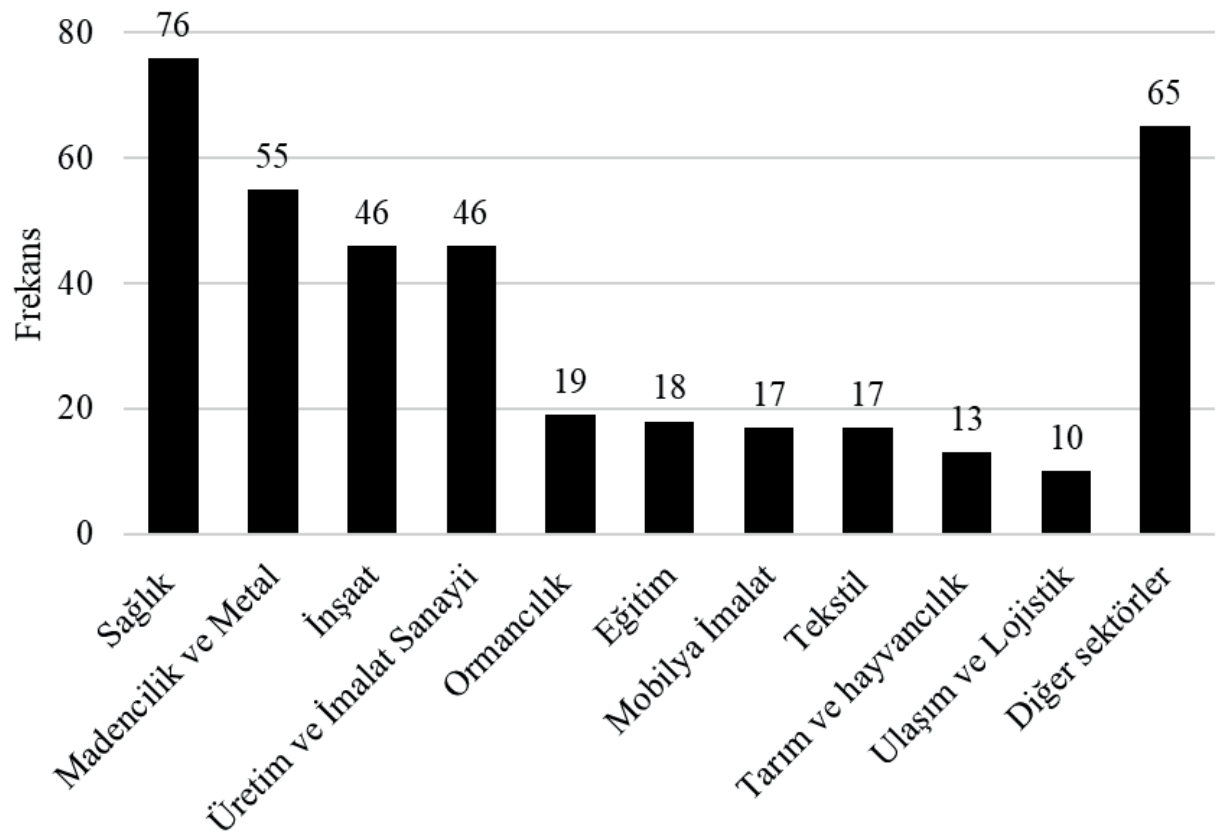

\section{Sektör}

Şekil 3. İSG Konusunda 2000-2019 Yılları Arasında Akademik Dergilerde Yayınlanan Makalelerde Araştırmaların Yapıldığı Sektörlere Göre Dağılımı.

Dördüncü adım olarak Türkçe yayınlarda kullanılan araştırma yöntemlerinin dağı̆l1$\mathrm{m}$ incelenmiştir. İSG konusunda yapılan çalışmalarda kullanılan araştırma yöntemlerinin dağılımı Şekil 4'te görülmektedir. Yapılan çalışmaların 188'inde (\%32) betimleyici kantitatif, 64'ünde (\%11) kalitatif, 45'inde (\%8) arşiv veri analizi, 34'ünde (\%6) özel olgu ya da uygulama incelemesi, 18'inde (\%3) tahminse kantitatif ve 4'ünde (\%1) anket geliştirme ya da uyarlama yöntemleri kullanılmıştır. Bunların dışındaki çalışmalarda belirgin bir araştırma yöntemi kullanılmamış ve bu çalışmalarda araştırmacılar tarafından yasa/politika tartışması yapılmış $(n=86 ; \% 15)$, görüş belirtilmiş $(n=72 ; \% 12)$ veya model/yöntem geliştirme/uygulaması $(n=44 ; \% 8)$ yapılmıştır. 


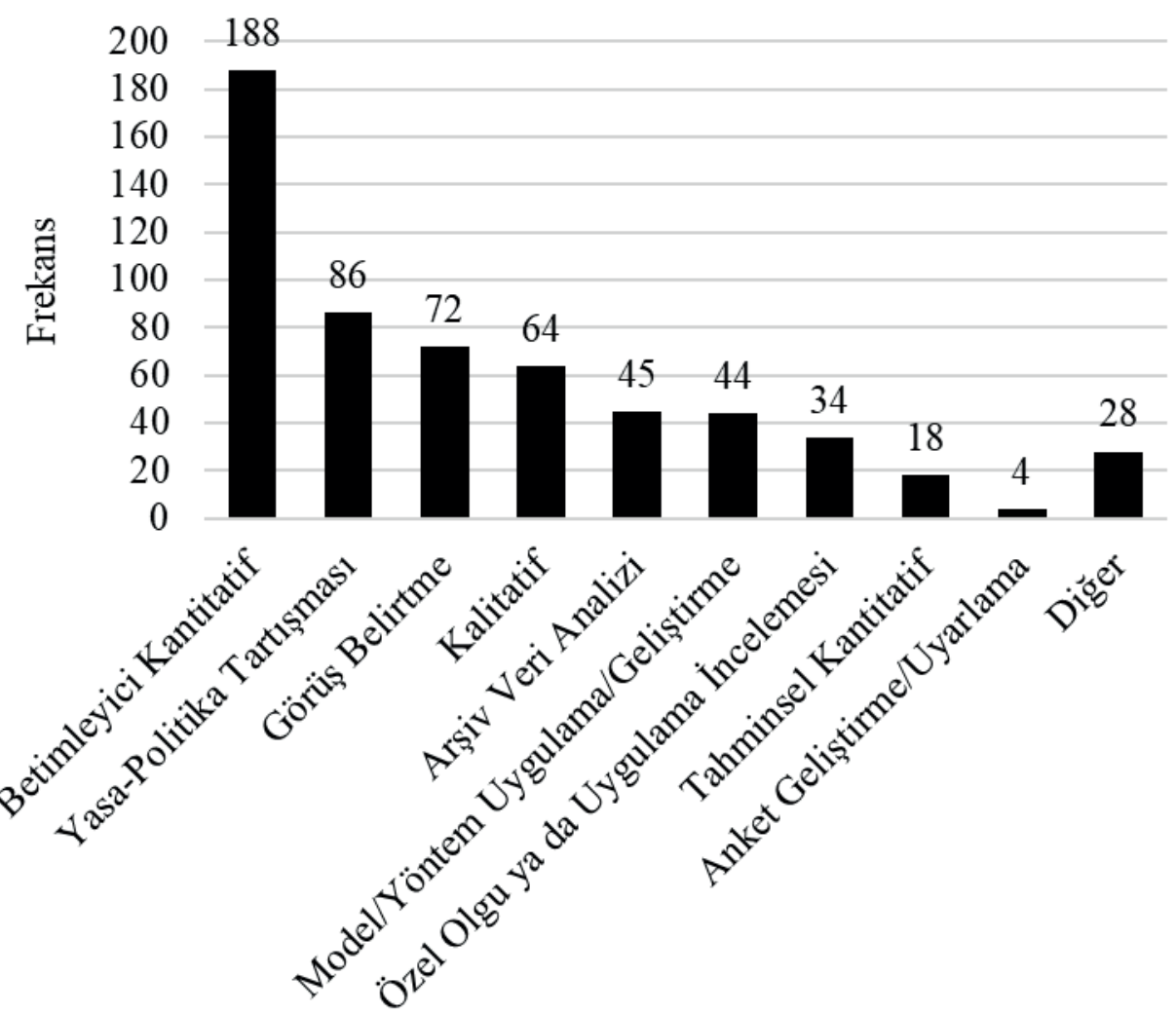

Araştırma Yöntemi

Şekil 4. İSG Konusunda 2000-2019 Yılları Arasında Akademik Dergilerde Yayınlanan Makalelerde Kullanılan Araştırma Yöntemlerinin Dağılımı.

Beşinci adım olarak analiz edilen "583 çalışmada ne sıklıkla hipotez testi uygulanmıştır?" sorusu cevaplanmaya çalışılmıştır. Yöntem kısmında verilen ölçüt doğrusunda yapılan kodlama sonucunda 583 çalışmadan sadece 16'sının (\%3) hipotez testi uyguladığı gözlemlenmiştir

Kantitatif çalışmalarda yordayıcı (predictor) ve ölçüt olarak kullanılan değişkenlere bakıldığında, araştırmacılar daha çok demografik değişkenleri yordayıcı değişken olarak kullanırken, ölçüt olarak ise iş kazası sayısı, iş kazası geçirmiş olmak gibi iş kazasına ilişkin değişkenleri kullanmışlardır. Türkçe çalışmalarda yordayıcı ve ölçüt olarak kullanılan değişkenlerin dağılımına ilişkin bilgi Tablo 2'de daha ayrıntılı bir şekilde verilmiştir. Türkçe çalışmalarda demografik değiş̧kenlere göre davranışı daha güçlü bir şekilde etkileyen algı, tutum, bilgi seviyesi, kişilik özellikleri ve durumsal faktörler gibi 
değişkenler daha az oranda yordayıcı değişken olarak kullanılmıştır. Ölçüt olarak ele alınan değişkenlere bakıldığında, Türkçe yapılan çalışmalarda güvenlik katılımı ve güvenlik uyumu gibi önemli değişkenlerin üzerinde yeterince durulmadığını gözlemlenmiştir.

Tablo 2. Türkçe Çalışmalarda Yordayıcı ve Sonuç Olarak Kullanılan Değişkenlerin Dağılımı

\begin{tabular}{llll}
\hline Kestirici olarak kullanılan değişkenler & & Sonuç olarak kullanılan değişkenler & Frekans \\
\hline Değişken & Frekans & Değişken & 11 \\
\hline Demografik özellikler & 17 & İş kazası & 11 \\
Çalışma koşulları & 14 & Meslek hastalıkları & 4 \\
Güvenlik iklimi & 7 & Fiziksel sağlık & 5 \\
Güvenlik kültürü & 4 & İş tutumları & 5 \\
Bireysel farklılıklar & 4 & Güvenli davranış & 3 \\
İş özellikleri & 3 & Psikolojik sağlık & 2 \\
İSG Eğitimi & 3 & Güvenlik iklimi & 1 \\
Güvenlik farkındalığı & 2 & Güvenlik kültürü & 5 \\
İş doyumu & 1 & Güvenlik uyumu & 2 \\
Güvenlik etkinliği & 1 & Güvenlik katılımı & 3 \\
İş kazasına uğramış olma & 1 & İSG Bilgi & 2 \\
Kapasite kullanımı & 1 & İSG tutum & 2 \\
İş yeri zorbalığı & 1 & Yaralanma & 1 \\
Yönetim kültürü & 1 & İş-aile, aile-iş çatışması & 1 \\
Maske kullanım tutumu & 1 & İş performansı & 1 \\
Raporlama kültürü & 1 & ÖVD & 1 \\
Güvenlik iletişimi & 1 & Güvenlik farkındalığı & \\
İş yeri hekimi çalıştırma & 1 & & \\
İSG algısı & 1 & & \\
İSG sorumlularının sertifika türü & 1 & &
\end{tabular}

Türkçe yapılan çalışmaların aldıkları atıf sayılarının dağılımı Şekil 5’te verilmiştir. Alınan atıf sayısı dağılımı incelendiğinde, 301 (\%52) çalışma hiç atıf almamış, 55 (\%9) çalışma bir atıf almış, 53 (\%9) çalışma iki atıf almış ve 29 (\%5) çalışma 3 atıf almıştır. Çalışmaların sadece 58'i (\%10) 11 ya da daha fazla sayıda atıf almıştır. Analize dahil edilen çalışmalardan Camkurt'un (2007) çalışma sistemleri ve işyeri fiziksel faktörlerinin iş kazalarına etkisini incelediği çalışma 144 atıf ile en fazla atıf alan çalışmadır. Özkılıç'ın (2005) İSG yönetim sistemleri ve risk değerlendirme yöntemlerini konu eden çalışması 160 atıf sayısıyla en fazla sayıda atıf alan çalışmalardan bir tanesidir. Fakat Özkılıç'ın çalışması akademik dergide yayınlanmış bir makale olmadığı için bu analizde yer alamamıştır. 


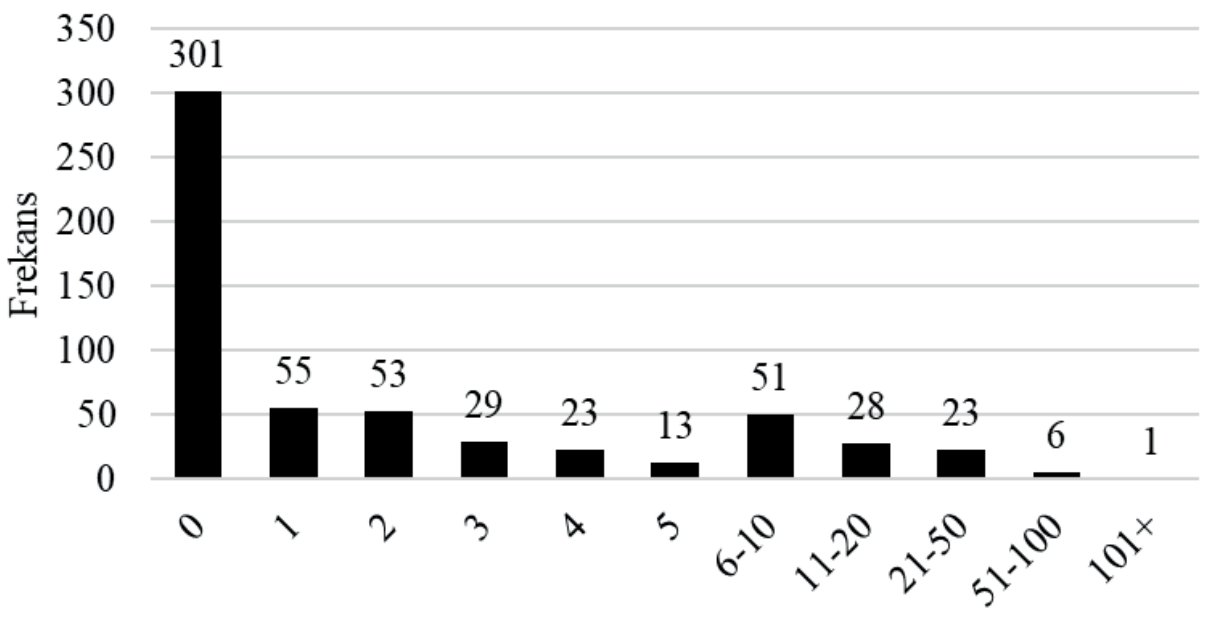

Atıf Sayıs1

Şekil 5: İSG Konusunda 2000-2019 Yılları Arasında Akademik Dergilerde Yayınlanan Makalelerde Aldıkları Atıf Sayısına Göre Dağılımları.

\section{Türkçe ve İngilizce Alan Yazın Karşılaştırmasına İlişsin Bulgular}

Y1llı ortalama en fazla atıf alan 101 İngilizce ve 101 Türkçe makale hipotez testi uygulayıp uygulamadıkları bakımından incelendiğinde 101 Türkçe makalenin sadece iki tanesinde hipotez testi uygulandığı gözlemlenirken, 101 İngilizce makalenin 45'inde hipotez testi uygulandığı gözlemlenmiştir (bkz. Şekil 6). Alan yazın ve hipotez testi uygulama değişkenleri arasında anlamlı bir ilişki olup olmadığını test etmek için Ki-kare bağımsızlık testi uygulanmıştır. Ki-kare testi sonucunda bu iki değişken arasında anlam11 bir ilişki bulunmuştur $\left.\left(X^{2}{ }_{1}=202\right)=51.27, p<.01\right)$. Bu sonuç doğrultusunda, yıllık ortalama en fazla atıf alan İngilizce çalışmalarda Türkçe yapılan çalışmalara oranla daha fazla hipotez testi uygulandığı anlaşılmaktadır. 


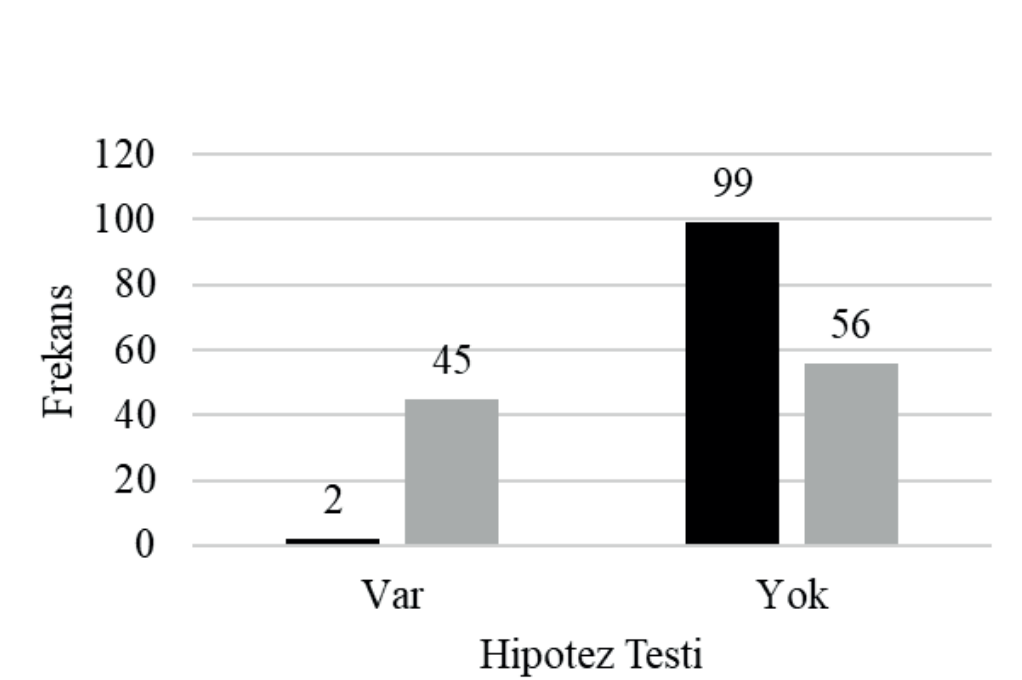

- Türkçe İngilizce

Şekil 6. İSG Konusunda Yayınlanan ve Yıllık Ortalama En Fazla Atıf Alan 101 Türkçe ve 101 İngilizce Makalede Hipotez Testi Uygulandığını/Uygulanmadığını Gösteren Frekans Dağılımı.

Türkçe ve İngilizce makalelerinin birinci yazarlarının en son eğitim aldıkları akademik alanlarının dağglımı Şekil 7'de verilmiştir. Bu dağglım incelendiğinde, Türkçe ve İngilizce alan yazın arasında çok çarpıcı farkların olduğu görülmektedir. Yıllık ortalama en fazla sayıda atıf alan 101 Türkçe çalışma dikkate alındığında, Türkçe alan yazına en fazla katkı sağlayanlar mühendislik ( $n=23)$ ve iktisadi ve idari bilimler kökenli $(n=21)$ araştırmacılardır. Türkçe İSG alan yazınına katkı bakımından tıp kökenli yazarlar üçüncü $(n=11)$, hukuk kökenli yazarlar dördüncü $(n=9)$, hemşirelik kökenli yazarlar beşinci $(n=7)$ ve İSG kökenli yazarlar $(n=6)$ altıncı sırada yer almıştır. Yı1lık ortalama en fazla sayıda atıf alan 101 İngilizce çalışma dikkate alındığında, İngilizce alan yazınına en fazla katkı sağlayanlar psikoloji kökenli araştırmacılardır ( $n=47)$. İngilizce İSG alan yazınına katkı bakımından mühendislik ( $n=12)$ ve iktisadi ve idari bilimler $(n=12)$ kökenli yazarlar ikinci sırayı paylaşmış ve tıp kökenli yazarlar $(n=9)$ dördüncü sırada yer almışlardır. Alan yazın ve araştırmanın birinci yazarının çalıştığı alan arasındaki ilişkiyi incelemek amacıyla Ki-Kare bağımsızlık testi uygulanmıştır. Ki-Kare testine sadece ilk beş sırada bulunan psikoloji, mühendislik, İ̈BF, tıp ve hukuk kategorileri dahil edilmiştir. Ki-kare testi sonucu alan yazın ve araştırmacının akademik alanı arasında istatistiksel olarak anlamlı bir ilişki bulunmuştur $\left.\left(X_{4}^{2}=144\right)=61.09, p<.01\right)$. 


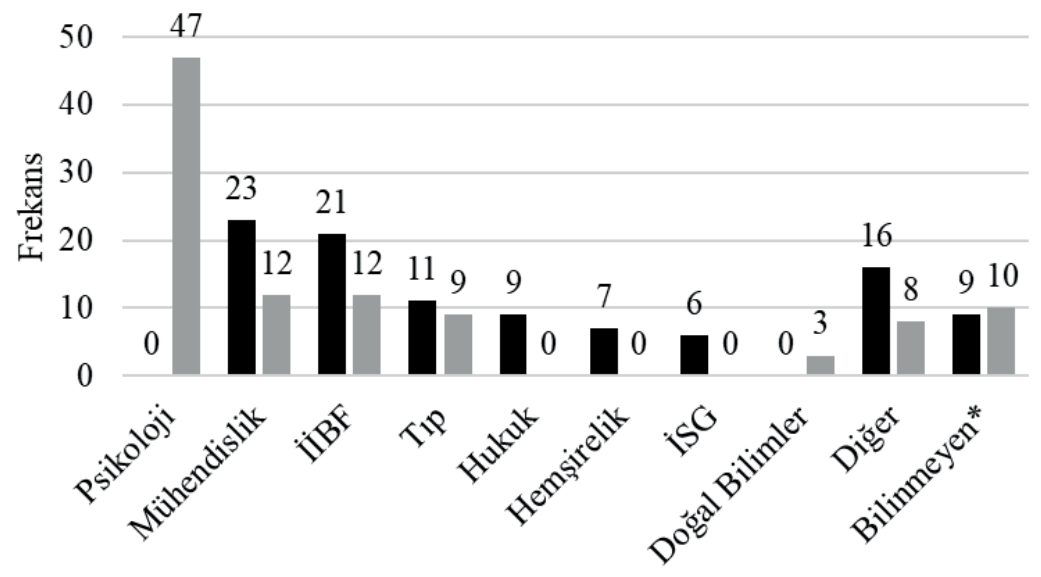

- Türkçe
— İngilizce

Birinci yazarın eğitim alanı

Şekil 7. İSG Konusunda Yayınlanan ve Yıllık Ortalama En Fazla Atıf Alan 101 Türkçe ve 101 İngilizce Makaledeki Birinci Yazarların Akademik Eğitim Alanlarına Göre Dağılımı.

Türkçe alan yazında en fazla atıf alan çalışmaların birinci yazarlarından hiçbiri psikoloji alanında çalışmazken, İngilizce alan yazına en fazla psikoloji kökenli araştırmacıların katkı yapmış olması, iki alan yazın arasındaki temel farkı oluşturmaktadır. Diğer önemli iki fark ise, mühendislik ve iktisadi ve idari bilimler kökenli araştırmacıların Türkçe ve İngilizce alan yazınlarına sundukları katkı oranlarında gözlemlenmektedir. Türkçe alan yazında mühendislik ( $n_{\text {Türkse }}=23 ; n_{\text {Ingilizce }}=12$ ) ve iktisadi ve idari bilimler kökenli araştırmacıların $\left(n_{\text {Türkse }}=21 ; n_{\text {Ingilizce }}=12\right)$ katkısının görece daha fazla olduğu gözlemlenmiştir.

İngilizce alan yazındaki en son mezun olduğu akademik alanları psikoloji olan 47 birinci yazarın 45'i doktora mezunu, biri uygulamalı psikoloji yüksek lisans mezunu ve bir tanesi de psikoloji lisans mezunudur. Doktora mezunu olan bu 45 psikoloğun 27'sinin anabilim dalı endüstri ve örgüt psikolojisi, 7'sinin ise örgüt psikolojisidir. Bu psikoloji doktoralı 45 yazar arasında psikolojinin sosyal, gelişim, eğitim, medikal ve psikometri anabilim dallarından doktorasını almış birer yazar bulunurken, altı yazarın psikoloji anabilim dalı bilgisine ulaşılamamıştır. Anabilim dalı bilgisine ulaşabilen 39 psikoloji doktora mezunun 34'ünün alanının endüstri ve örgüt psikolojisi ya da örgütsel psikoloji olduğu düşünüldüğünde, endüstri ve örgüt psikolojisi anabilim dalının İngilizce İSG alan yazınına yaptığı katkı açık bir şekilde görülmektedir. 
Türkçe ve İngilizce makalelerde uygulanan araştırma yöntemlerine ilişkin dağılım Şekil 8'de verilmiştir. Bu dağılım incelendiğinde, Türkçe ve İngilizce alan yazın arasında yine çok çarpıcı farkların olduğu görülmektedir. Yıllık ortalama en fazla atıf alan 101 Türkçe çalışma dikkate alındığında, Türkçe alan yazında en fazla betimsel kantitatif $(n=27)$, kalitatif $(n=20)$ ve arşiv veri analizi $(n=11)$ yöntemleri kullanıldığı görülmüştür. Bunun dışında dikkate değer sayıda çalışmada herhangi bir araştırma yöntemi kullanılmamış, yasa-politika tartışması yapılmış $(n=22)$ ya da görüş belirtilmiştir $(n=9)$. Y1llık ortalama en fazla atıf alan 101 İngilizce çalışma dikkate alındığında, İngilizce alan yazında en fazla tahminsel kantitatif $(n=36)$, literatüre incelemesi $(n=30)$ ve meta-analiz $(n=13)$ araştırma yöntemleri kullanıldığı görülmüştür. Alan yazın ve uygulanan araştırma yöntemi arasındaki ilişkiyi incelemek amacıyla Ki-Kare bağımsızlık testi uygulanmıştır. Ki-Kare testine sadece arşiv veri analizi, literatüre incelemesi, meta analiz, model uygulama/sunma, kalitatif, betimsel kantitatif ve tahminsel kantitatif araştırma yöntemleri dahil edilmiştir. Ki-kare testi sonucu alan yazın ve uygulanan araştırma yöntemi arasında istatistiksel olarak anlamlı bir ilişki bulunmuştur $\left.\left(X_{6}^{2}=157\right)=108,14, p<.01\right)$. $\mathrm{Bu}$ sonuç doğrultusunda İngilizce alan yazında daha fazla sayıda tahminsel kantitatif araştırma yapılırken, Türkçe alan yazında daha fazla betimsel kantitatif araştırma yapıldığı söylenebilir. Bunun dışında en çok atıf alan 101 İngilizce makalenin 30'nun alan yazın incelemesi olması ve en çok atıf alan 101 Türkçe makalenin hiçbirinin alan yazın incelemesi içermemesi dikkat çeken bir durumdur. 


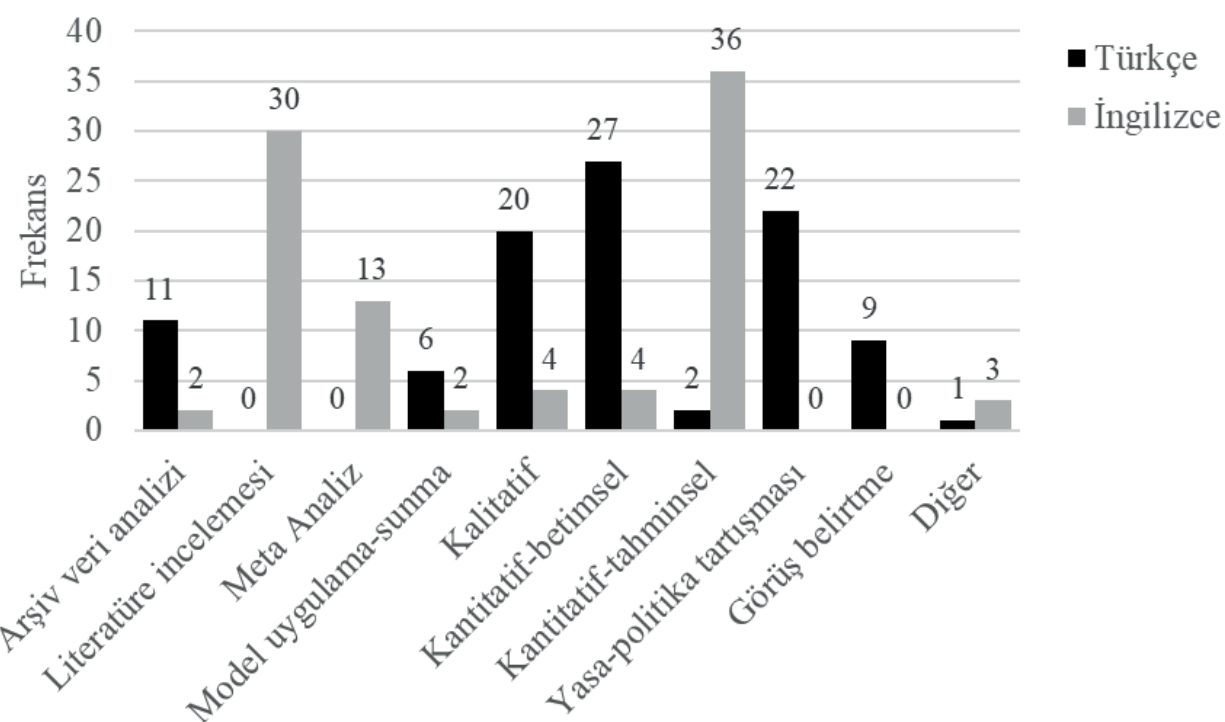

Araştırma Yöntemi

Şekil 8. İSG Konusunda Yayınlanan ve Yıllık Ortalama En Fazla Atıf Alan 101 Türkçe ve 101 İngilizce Makaledeki Araştırma Yöntemlerinin Dağılımı.

Türkçe ve İngilizce makaleleri içerdikleri yordayıcı ve sonuç değişkenler açısından incelemek için karşılaştırmalı bir tablo oluşturulmuştur (bkz. Tablo 3). Yapılan inceleme sonucunda en çok sayıda atıf alan 101 Türkçe makalenin sadece 9'unda, 101 İngilizce makalenin ise 51'inde yordaycı ve sonuç değişken kullanıldı ğı gözlemlenmiştir. Sonuç ve yordayıcı değişken içeren Türkçe makalenin az olması nedeniyle anlamlı düzeyde bir karşılaştırma yapılması mümkün olmamıştır. Buna rağmen İngilizce alan yazında en fazla üzerinde durulan yordayıcı ve sonuç değişkenleri anlamak adına Tablo 3'teki verilerin önemli olduğu düşünülmektedir. İngilizce alan yazında yordayıcı değişken olarak güvenlik iklimi, iş özellikleri, iş tutumları ve güvenliğe ilişkin diğer değişkenler (yani güvenlik bilgisi, güvenlik motivasyonu, güvenlik bağl1lı̆̆, güvenlik iletişimi, güvenlik yönetimi ve güvenlik politika ve uygulamaları); sonuç değişken olarak ise sağlık ve iyi oluş, kaza/yaralanma, iş tutumları, güvenli davranış, güvenlik uyumu, güvenlik katılımı ve güvenlik performansı karşımıza çıkmaktır. 
Tablo 3. En fazla atıf alan 101 Türkçe ve İngilizce Makaledeki Yordayıcı ve Sonuç Olarak Kullanılan Değişkenlerin Dağılımı

\begin{tabular}{llll}
\hline Türkçe Makaleler & & İngilizce Makaleler & Frekans \\
\hline Yordayıcı Değişken & Frekans & Yordayıc Değişken & 19 \\
\hline Güvenliğe iliş̧kin değişkenler & $4 *$ & Güvenlik iklimi & $12^{* *}$ \\
Demografik özellikler & 3 & Güvenliğe ilişkin diğer değişkenler & 9 \\
Çalışma koşulları & 2 & İş özellikleri & 9 \\
Diğer yordayıcı değişkenler & 7 & İş tutumları & 5 \\
& & Örgüt özellikleri & 5 \\
& & Liderlik & 21 \\
\hline Sonuç Değişkenler & & Diğer yordayıcı değişkenler & Frekans \\
\hline Güvenli davranış & Frekans & Sonuç Değişkenler & 16 \\
Güvenlik katılımı & 3 & Sağlık ve iyi oluş & 14 \\
Güvenlik uyumu & 2 & Kaza/yaralanma & 7 \\
Sağlık & 2 & İş tutumları & 6 \\
Kaza geçirme & 2 & Güvenli davranış & 5 \\
İSG bilgi düzeyi & 2 & Güvenlik uyumu & 5 \\
Diğer sonuç değişkenler & 2 & Güvenlik katılımı & 5 \\
& 2 & Güvenlik performansı & $11^{* * *}$ \\
\hline
\end{tabular}

Not. Yordayıcı ve sonuç değişken içeren Türkçe makale sayısı 9, İngilizce makale sayısı ise 51 olarak bulunmuştur; * Güvenlik kültürü, güvenlik farkındalığı, güvenlik iletişimi ve güvenlik etkinliği değişkenleri; ** Güvenlik bilgisi, güvenlik motivasyonu, güvenlik bağlılığı, güvenlik iletişimi, güvenlik yönetimi ve güvenlik politika ve uygulamaları; *** Çalışan güvenliğì, güvenlik iklimi, güvenlik bağlllı̆̆ı, algilanan güvenlik, güvenlik yönetimi ve güvenlik bilgisi.

\section{TARTIŞMA}

Bu çalışmada 2000 ve 2019 yılları arasında İSG alanında yayınlanan ve Google Scholar'dan erişilen akademik bir dergide yayınlanmış Türkçe çalışmalar incelenerek Türkçe İSG alan yazınının genel bir resmini çizilmeye çalışılmıştır. Ayrıca, Türkçe ve İngilizce İSG alan yazınları arasında belli konularda karşılaştırma yapılarak, Türkçe alan yazının hangi yönlerden eksiklikler içerdiği saptanmaya çalışılmıştır. Bu çalışmada saptanan eksiklikler doğrultusunda sunulan önerilerin Türkçe İSG alan yazına katkı sağlayacağı düşünülmektedir. İSG gibi çalışan hayatını ve sağlığını doğrudan etkileyen konularda yapılan çalışmaların daha sistematik olması, bu alandaki uygulanabilir bilgi birikiminin artmasına doğrudan katkı yapacaktır. Bu alandaki uygulanabilir bilgi birikimi arttıkça İSG'ye ilişkin geliştirilen politikaların ve uygulamaların daha kapsayıcı ve daha başarılı olması beklenmektedir.

Türkçe İSG alan yazınına ilişkin bu çalışma kapsamında yapılan analizlerin genel sonuçları dikkate alındığında, İSG konusunda yapılan araştırmaların sayısının ve niteli- 
ğinin artırılması gerektiği görülmektedir. Şekil 1'de verilen İSG konusunda Türkçe yapılan yayınların yıllara göre dağılımı incelendiğinde 2014 yılında meydana gelen Soma maden faciasının (Yaşar ve ark., 2015) sonrasında yayın sayısında yaklaşık iki kat bir artış olduğu, sonraki iki yılda ise yapılan yayın sayısında düşüş olduğu görülecektir. Fakat 2019 yılında bir önceki yıla göre dikkate değer (\%89) bir artış olduğu da ortaya çıkan sonuçlardan biridir. Buna göre, son üç yılda yapılan yayın sayısında sürekli bir artışın olması İSG'nin gündeme gelme ve gündemde kalma düzeyine olumlu katkı sağlayacağı düşünülmektedir.

Elde edilen bulgular 1şığında Türkçe İSG alan yazına ilişkin yapılabilecek en önemli değerlendirmelerden birisi Türkçe yapılan çalışmalarda İSG performansıyla doğrudan ilişkili değişkenlerin yeterince incelenmediğidir. İSG üzerine yapılan meta-analizler (bkz. Christian, Bradley, Wallace ve Burke, 2009; Clarke, 2010, 2013; Nahrgang ve ark., 2011) ve en çok atıf alan İngilizce makaleler (bkz. Hofmann ve Morgeson, 1999; Neal, Griffin ve Hart, 2000; Zohar, 2000) dikkate alındığında İngilizce İSG alan yazınında araştırmacıların çalışmalarında İSG performansıyla doğrudan ilişkili güvenlik kültürü, güvenlik iklimi, psikolojik iklim, liderlik, grup içi süreçler, işe ilişkin riskler, iş tutumları ve tükenmişlik gibi yordayıcı değişkenler üzerine durdukları açık bir şekilde gözlemlenmektedir. Türkçe yapılan çalışmalarda ise araştırmacıların yordayıcı değişken olarak daha çok demografik özellikler ve çalışma koşulları üzerinde durdukları görünmektedir. Y1llık ortalama en fazla atıf alan İngilizce makalelerin etki düzeyinin yüksek olduğu düşünüldüğünde, İSG ile doğrudan ilişkili değişkenlere yer vermesi Türkçe makalelerin etki düzeyine olumlu katk1 yapabilir.

Ayrıca Türkçe alan yazında sonuç değişsken olarak iş kazası, yaralanma ve mesleki hastalık gibi değişkenlere yer verildiği ama güvenli olmayan davranış, ramak kala olay ve riskli temas gibi sonuç değişkenlerinin ise yeterince dikkate alınmadığı gözlemlenmiştir. Güvenli olmayan davranış, riskli temas ve ramak kala olay gibi değişkenleri dikkate almamak şirketlerin ya da grupların ISG performansına bütüncül bir şekilde yaklaşmasını engelleyebilir. Bu sonuç değişkenlerinin de çalışmalara dahil edilmesi için işyerlerinde İSG raporlama kültürünün gelişmiş olması gerektiği düşünülmektedir. Uluslararası Çalışma Örgütü’nün (2017) verileri dikkate alındığında, ülkemizde riskli temas ya da ramak kala olayların raporlanması bir yana, sigortaya intikal edecek derecede ciddi bir yaralanmaya yol açmayan iş kazalarının raporlanmasında bile eksiklik gözlemlenmektedir. 
Türkçe İSG alan yazına ilişkin yapılan diğer önemli değerlendirme ise Türkçe araştırmalarda kullanılan yönteme ilişkindir. Analize dahil edilen çalışmaların 206 tanesi kantitatif araştırma yöntemi kullanmış ve bu çalışmalardan 188 tanesinde betimsel yöntemlerle veriler analiz edilirken sadece 18 tanesinde tahminsel yöntemler kullanılmıştır. Benzer şekilde en çok atıf alan 101 Türkçe ve İngilizce makale karşılaştırıldığında, Türkçe makalelerde daha az sayıda tahminsel kantitatif (2'ye karşı 36) ve daha çok sayıda betimsel kantitatif (27'ye karşı 4) araştırma yöntemi kullanıldı̆̆ı görülmüştür. Tahminsel yöntemlerin özünü oluşturan hipotez geliştirme ve test etme bilimsel yöntemin temel unsurlarından biridir (Popper, 1959). Ayrıca, kavramsal (conceptual) ve yöntemsel (procedural) bilgiye bütüncül bir şekilde ulaşmak için kullanabilecek en etkili yollardan biri yine hipotez testidir (Howe, Tolmie, Duchak- Tanner ve Rattray, 2000). ISSG konusunda yapılan 583 bilimsel çalışmanın sadece 16 tanesinde hipotez testi uygulanmış olması, Türkçe İSG alan yazında hipotez geliştirip test etme noktasında önemli bir açığın olduğunu göstermektedir. Bu doğrultuda, bilimsel ve kapsamlı bilgi birikimi oluşturmak için hipotez testi içeren çalışmaların sayısının artması gerektiği düşünülmektedir.

Yapılan değerlendirmelerden belki de en önemlisi İSG konusunda Türkçe alan yazında bilimsel anlamda bütüncül bir bakış açısının yerleşmemiş olmasıdır. Türkçe İSG alan yazınının mühendislik, tıp ve iktisadi ve idari bilimler alanına sıkışmış olduğu, psikoloji gibi davranış üzerine eğilen bilim dallarının bu alana katkısının çok sınırlı kaldığ1 gözlemlenmiştir. Psikolojinin kazandıracağı davranış odaklı bakış açısının ne derece önemli olduğunu anlamak için, yıllık bazda ortalama en çok sayıda atıf alan 101 İngilizce makaleden 47'sinin birinci yazarının en son eğitim aldığı akademik alanının psikoloji olduğunu bilmek yeterlidir. Bu manada İngilizce İSG alan yazını psikolojinin sağladı̆̆ı bakış açısından faydalanırken, Türkçe alan yazını bu bakış açısından neredeyse tamamen mahrum kalmıştır. Analize dahil edilen 583 makaleden sadece bir tanesinin birinci yazarının psikoloji alanından olması bu görüşü desteklemektedir. Ayrıca, Mutlu ve Altuntaş'ın (2017) İSG hakkında yazılan lisansüstü tezleri inceledikleri araştırmalarında, çalışmalarına dahil ettikleri 795 lisansüstü tezin sadece üç tanesi psikoloji bölümü lisansüstü öğrencileri tarafından yazılmıştır. Bu durum Türkiye'de psikoloji alanında çalışan araştırmacıların İSG'ye ilişkin görüşlerinin, anlayışlarının ve önerilerinin henüz İSG alanında yer edinmediğinin başka bir göstergesidir. İSG, psikolojinin anabilim dallarından biri olan endüstriyel ve örgütsel (E/Ö) psikolojinin temel çalışma 
alanlarından biridir. Zaten yıllık ortalama en fazla sayıda atıf alan İngilizce İSG makalelerinin birinci yazarlarından anabilim dalı bilgisine ulaşabildiğimiz psikoloji doktoral1 39 yazarın 34'ünün endüstri ve örgüt ya da örgüt psikolojisi alanında doktoralarını yapmış olmaları bu görüşü desteklemektedir. Bu doğrultuda psikoloji biliminin bakış açısının Türkçe İSG alan yazınında hemen hemen hiç yer edinmemiş olmasının temel nedenlerinden biri olarak E/Ö psikolojinin ülkemizde yeni yeni gelişmeye başlamış olması düşünülebilir. E/Ö psikolojisi bir anabilim dalı olarak geliştikçe, psikoloji biliminin bakış açısının Türkçe İSG alan yazınında kendine önemli bir yer edineceği düşünülmektedir.

\section{Çalışmanın Sınırlılıkları ve Alana Öneriler}

Okurların bu çalışmaya ilişkin bulguları yorumlarken dikkate almaları gereken ve çalışmanın çerçevesini sınırlayan durumlar vardır. İlk olarak bu çalışmaya 2000 ve 2019 yılları arasında yapılan ve Google Scholar'da ulaşıma açık olan akademik dergi makaleleri dahil edilmiştir. Her ne kadar hızlı bir şekilde yapılmış olan alan yazın taraması, psikoloji biliminin 2000 yılı ve öncesinde de Türkçe İSG alanında yeterli bir şekilde temsil edilmediğini göstermiş olsa da, bu çalışmaya ilişkin bulguların 2000 ve 2019 yılları arasında yapılan çalışmalar ışı̆̆ında elde edildiği unutulmamalıdır.

Bulguları sınırlayan ikinci faktör ise bu çalışmaya sadece Türkçe yayınlanan makalelerin dahil edilmiş olmasıdır. Türk araştırmacılar tarafından İngilizce ya da diğer dillerde yayımlanan makalelerin Türkçe yayımlanan makalelerden içerik ve yöntem olarak farklılaşması olasılık dahilindedir.

Bulguları sınırlayan üçüncü faktör ise yapılan çalışmalar kodlanırken bazı durumlarda kaçınılmaz olarak kişisel görüş kullanılmış olmasıdır. Örneğin, bazı çalışmalarda yazarlar hipotez belirtmiş olsa da bu hipotezlere ilişkin herhangi bir ön tartışma yapmadılarsa, bu çalışmalar hipotez testi uygulamış çalışmalar olarak kodlanmamıştır. Daha önce de açıklandığı gibi, hipotezlerin çalışmaya başlamadan önce oluşturulmuş olması ya da araştırmacının hipotezde belirtilen etkiye ya da ilişkiye dair bir öngörüsünün olması gerekmektedir. Bu nedenle, eğer araştırmacılar hipotezlerinde belirtilen etkileri ya da ilişkileri hipotezleri belirtmeden önce açık bir şekilde tartışmamışlarsa, bu araştırmacıların hipotezleri önceden oluşturmadıklarını ya da hipotezlerde belirttikleri etkilere ya da ilişkilere dair bir öngörülerinin olmadıkları varsayılmıştır. Bu durum bir dereceye kadar kişisel bir tutumu belirtmektedir. 
Yapılan analiz sonuçlarına göre son yıllarda İSG konusunda yayımlanan Türkçe makale sayısında bir artış gözlemlenmiştir. İSG konusunda yapılan yayınların sayısının artması umut verici bir gelişme olsa da bu durumun İSG konusunda yol alabilmek için tek başına yeterli olmayacağı düşünülmektedir. Türkçe yayın sayısının artırılmasından daha elzem olan konu yapılan yayınların içeriğinin zenginleştirilmesidir. İngilizce ve Türkçe makaleler arasında yapılan karşılaştırmalı analiz neticesinde Türkçe yayınların içeriğini zenginleştirmek adına birbiriyle bağlantılı üç öneri geliştirilmiştir. Bu amaçla atılması gereken ilk adım daha önce Tablo 2'de de görüldüğü gibi demografik değişkenlerin ötesinde, İngilizce alan yazında olduğu gibi Türkçe alan yazında da İSG performansıyla doğrudan ilişkili güvenlik kültürü, güvenlik iklimi, psikolojik iklim, liderlik, grup içi süreçler, işe ilişkin riskler, iş tutumları ve tükenmişlik gibi değişkenlerin daha çok dikkate alınmasıdır. İkinci olarak atılması gereken adım, İSG konusunda yapılan kantitatif çalışmalarda betimsel analizlerin ötesine geçerek, tahminsel analizlere yönelip uygulanabilir bilginin üretilmesidir. Üçüncü olarak atılması gereken adım ise, İSG konusunun farklı bilimsel alanların bakış açısı 1şığında bütüncül bir şekilde ele alınmasıdır. Özellikle psikoloji eğitimi almış araştırmacıların İSG konusu üzerine eğilmeleri, mühendislik, tıp ve iktisadi ve idari bilimler alanına sıkışmış ISG konusuna yeni bir bakış açısı kazandiracaktır.

$\mathrm{Bu}$ önerilere ek olarak ülkemizdeki iş kazası raporlama konusunda gözlemlenen eksiklikler dikkate alındığında (Uluslararası Çalışma Örgütü, 2017), bu eksiklikleri ortadan kaldırmak adına iş kazası raporlama kültürünün önemine işaret eden ve kapsayıcı bir raporlama kültürü oluşturmak için dikkat edilmesi gereken noktaların belirtildiği Türkçe yayınlar yapılmalıdır. Bu yayınlarda ramak kala olay, riskli temas ve güvenli olmayan davranış gibi değişkenlerin de raporlanmasının önemine ve nasıl raporlanması gerektiğine yer verilmelidir.

Son olarak, hipotez geliştirme ve test etmenin bilimsel yöntemin temel unsurlarından biri olduğu unutulmamalıdır (Popper, 1959). Bu nedenle İSG konusunda yapılan çalışmaların bilimsel açıdan niteliğini artırmak ve İSG'ye ilişkin tarafların yararlanabileceği bilimsel ve görece objektif bilgi birikimi oluşturmak için İSG konusundaki Türkçe çalışmaların daha fazla oranda hipotez testine yer vermesi sağlanmalıdır.

Bu çalışmada Türkçe ve İngilizce İSG alan yazın arasında bulunan temel farkların nedeninin ne olabileceği yönünde bir tartışmada bulunulmamıştır. Bu farkların kültürel 
normlar, eğitim ve araştırma olanakları, işe ilişkin politika ve uygulamalar gibi faktörlerden kaynaklanıyor olması muhtemeldir. Bu faktörlere ilişkin yapılacak derinlemesine bir tartışmanın bu araştırmanın amacının ötesinde olduğu düşünülmektedir. İSG alanında çalışan araştırmacıların Türkçe ve İngilizce alan yazın arasında ortaya koyulan bu farklara yol açan faktörler üzerine düşünmeleri ve bu konuda araştırma yapmaları beklenmektedir.

\section{SONUÇ}

Türkiye'deki işçi yaralanmalarına ve ölümlerine ilişkin istatistikler ve medya organlarında sıklıkla karşılaşılan ölümcül işçi kazalarına dair haberler dikkate alındığında, İSG alanında hızlı bir şekilde iyileşme sağlanması gerektiği görülmektedir. Bu iyileşmenin sağlanabilmesi için İSG konusuna taraf olan kurumlar üzerlerine düşen görevleri en iyi şeklide yapması gerekmektedir. İSG ile ilgili taraflardan kasıt SGK ve Aile, Çalışma ve Sosyal Hizmetler Bakanlığg gibi kamu kurumları, işçi ve işveren örgütleri, iş yeri yöneticileri, işçiler ve İSG konusundaki bilgi ve birikimin artmasına doğrudan katk1 sağlaması gereken akademik camiadır. Bu çalışmada İSG konusunda yayınlanan Türkçe makaleler incelenerek, İSG konusunda uygulanabilir bilgi birikiminin artmasına doğrudan katkı sağlaması beklenen akademik camianın bu görevi ne derece başarılı bir şekilde yerine getirdiği anlamaya çalışılmıştır. Araştırmanın sonuçları göstermiştir ki akademik camia, bu haliyle, İSG alanındaki sorunların çözümüne anlamlı bir katkı yapmaktan uzaktır.

Akademik camia mensuplarının bu konuda üzerlerine düşen görevi en iyi şekilde yerine getirmesi için her şeyden önce reaktif bir tutum göstermek yerine, proaktif bir tutum izlenmesi gerekmektedir. Bu bağlamda İSG konusu sadece büyük iş kazalarının olduğu zamanlarda değil, her daim akademik camianın gündeminde olmalıdır. Soma' da 2014 yılında meydana gelen iş kazasından sonra herhangi büyük bir iş kazası yaşanmamasına rağmen 2019 yılındaki yapılan yayın sayısındaki artış akademik camianın proaktif bir tutum izlemeye başlamış olabileceği konusunda umut vermektedir. İkinci olarak, yapılacak çalışmalardan elde edilecek bilgilerin ne derece uygulanabilir olduğuna dikkat edilmelidir. Betimsel çalışmalar her ne kadar İSG ile ilgili sorunların mahiyetini anlamamıza olanak sağlasa da bu sorunları gidermek için uygulanabilir bilgi üretme konusunda yeterli değildir. Uygulanabilir bilgi üretmek için araştırmacıların çalışmalarında demografik değişkenler yerine daha çok İSG ile doğrudan ilişkili güvenlik iklimi, güvenlik kültürü, liderlik, grup içi süreçler ve işe ilişkin riskler gibi değişkenlerin üze- 
rinde durmaları gerekmektedir. Planlanmış davranış (Ajzen, 1991), sosyal öğrenme (Bandura, 1962, 1965) ve yükleme teorileri (Jones ve Davis, 1965; Kelley, 1967, 1973) gibi davranışın ve tutumların altında yatan mekanizmaları anlamamıza yarayan modellerden faydalanarak geliştirilmiş hipotezleri test etmek, araştırmacıların uygulanabilir bilgi üretmesine katkı sağlayacaktır. Bunların gerçekleşmesi için davranış ve tutum çalışma konusunda teorik ve yöntemsel yeterliliğe sahip araştırmacıların İSG alanına yönelmesi ya da yönlendirilmesi gerekmektedir. Bu doğrultuda yüksek lisans ya da doktora eğitimini psikoloji ve diğer davranış bilimleri alanında tamamlamış olan araştırmacıların Türkçe İSG alan yazınına önemli katkılar yapma potansiyeline sahip oldukları düşünülmektedir. Endüstri ve örgüt psikolojisi doktora eğitimli araştırmacıların İngilizce İSG alan yazınına yaptıkları önemli katkılar düşünüldüğünde, Türkçe İSG alan yazınının bu şekilde bir katkıdan yararlanabilmesi için yüksek lisans ya da doktora eğitimini endüstri ve örgüt psikolojisinde tamamlamış olan ülkemizdeki araştırmacıların İSG alanına yönelmelerini teşvik etmek gerekmektedir.

Teşekkür: Makaleyi Psikoloji Çalışmaları Dergisi’ne ilk defa gönderdiğimizde önemli ve yapıcı geribildirim sağlayan hakemlere teşekkür ederiz.

Hakem Değerlendirmesi: Dış bağımsız.

Çıkar Çatışması: Yazarlar çıkar çatışması bildirmemiştir.

Finansal Destek: Yazarlar bu çalışma için finansal destek almadığını beyan etmiştir.

Peer-review: Externally peer-reviewed.

Conflict of Interest: The authors have no conflict of interest to declare.

Grant Support: The authors declared that this study has received no financial support.

\section{Kaynakça/References}

Ajzen, I. (1991). The theory of planned behavior. Organizational Behavior and Human Decision Processes, 50(2), 179-211.

Anadolu Ajansı (2012). Elektrik Kontağı Şüphesi. Erişim adresi: https://www.aa.com.tr/tr/turkiye/ elektrik-kontagi-suphesi/377781

Anadolu Ajansı (2014). Şişli’deki Asansör Kazasında 10 İşçi Hayatını Kaybetti. Erişim adresi: https:// www.aa.com.tr/tr/turkiye/sislideki-asansor-kazasinda-10-isci-hayatini-kaybetti/124450

Association for Safe International Road Travel (2017). Annual Global Road Crash Statistics. Erişim adresi: http://asirt.org/Initiatives/Informing-Road-Users/Road-Safety-Facts/Road-Crash-Statistics

Bandura, A. (1962). Social learning through imitation. M. R. Jones (Ed.), Nebraska symposium on motivation: 1962 içinde (s. 211- 269). Lincoln: Univer. Nebraska Press. 
Bandura, A. (1965). Vicarious processes: A case of no-trial learning. Advances in Experimental Social Psychology, 2, 1-55.

Boyd, A. (1997). Employee traps-corruption in the workplace. Management Review, 86(8), 9-10.

Burke, M. J. ve Signal, S. (2010). Workplace safety: A multilevel, interdisciplinary perspective. J. J. Martocchio, H. Liao, \& A. Joshi (Ed.), Research in personnel and human resource management içinde (s. 1-47). Bingely, United Kingdom: Emerald Group Publishing Limited.

Camkurt, M. Z. (2007). İşyeri çalişma sistemi ve işyeri fiziksel faktörlerinin iş kazalari üzerindeki etkisi. TÜHİ İş Hukuku ve İktisat Dergisi, 21(1), 80-106.

Ceylan, H. (2011). Türkiye'deki iş kazalarının genel görünümü ve gelişmiş ülkelerle kıyaslanması. International Journal of Engineering Research and Development, 3(2),18-24.

Christian, M. S., Bradley, J. C., Wallace, J. C. ve Burke, M. J. (2009). Workplace safety: A meta-analysis of the roles of person and situation factors. Journal of Applied Psychology, 94(5), 1103-1127.

Clarke, S. (1998). Organizational factors affecting the incident reporting of train drivers. Work \& Stress, 12(1), 6-16. doi:10.1080/02678379808256845

Clarke, S. (2010). An integrative model of safety climate: Linking psychological climate and work attitudes to individual safety outcomes using meta-analysis. Journal of Occupational and Organizational Psychology, 83(3), 553-578.

Clarke, S. (2013). Safety leadership: A meta-analytic review of transformational and transactional leadership styles as antecedents of safety behaviours. Journal of Occupational and Organizational Psychology, 86(1), 22-49. doi:10.1111/j.2044- 8325.2012.02064.x

Costa, G. (2003). Shift work and occupational medicine: An overview. Occupational Medicine, 53, 83-88.

Danna, K. ve Griffin, R. W. (1999). Health and well-being in the workplace: A review and synthesis of the literature. Journal of Management, 25(3), 357-384.

Dembe, A. E. (2001). The social consequences of occupational injuries and illnesses. American Journal of Industrial Medicine, 40(4), 403-417.

Dollard, M. F. ve Bakker, A. B. (2010). Psychosocial safety climate as a precursor to conducive work environments, psychological health problems, and employee engagement. Journal of Occupational and Organizational Psychology, 83, 579-599.

Dul, J. ve Neumann, W. P. (2009). Ergonomics contributions to company strategies. Applied Ergonomics, $40(4), 745-752$.

Gruber, J. ve Morgan, P. (2005). In the company of men: Male dominance and sexual harassment. Boston: Northeastern University Press.

Harzing, A. W. (2007). Publish or Perish. Erişim adresi: https://harzing.com/resources/publish-orperish

Hämäläinen, P., Takala, J. ve Saarela, K. L. (2006). Global estimates of occupational accidents. Safety Science, 44, 137-156.

Hershcovis, M. S., Turner, N., Barling, J., Arnold, K. A., Dupré, K. E., Inness, M., LeBlanc, M. ve Sivanathan, N. (2007). Predicting workplace aggression: A meta-analysis. Journal of Applied Psychology, 92(1), 228-238.

Hofmann, D. A. ve Morgeson, F. P. (1999). Safety-related behavior as a social exchange: The role of perceived organizational support and leader-member exchange. Journal of Applied Psychology, 84, 286-296.

Howe, C., Tolmie, A., Duchak-Tanner, V. ve Rattray, C. (2000). Hypothesis testing in science: Group consensus and the acquisition of conceptual and procedural knowledge. Learning and Instruction, 10(4), 361-391. 
İncesu, E. ve Atasoy, A. (2015). Hemşirelerin çalışan sağlığı ve güvenliği kültürü algılarının çalışan sağlı̆̆1 ve güvenliği kültürü ölçeği kullanılarak incelenmesi. Sağllk Akademisyenleri Dergisi, 2(3), $119-126$.

Jones, E. E. ve Davis, K. E. (1965). From acts to dispositions the attribution process in person perception. Advances in Experimental Social Psychology, 2, 219-266. doi:10.1016/S0065-2601(08)60107-0

Jones, S., Kirchsteiger, C., ve Bjerke, W. (1999). The importance of near miss reporting to further improve safety performance. Journal of Loss Prevention in the Process Industries, 12(1), 59-67.

Kelley, H. H. (1967). Attribution theory in social psychology. Nebraska symposium on motivation, 15, 192-238.

Kelley, H. H. (1973). The processes of causal attribution. American Psychologist, 28(2), 107-128.

Kılkış, İ. (2013). İş sağlığı ve güvenliğinde yeni dönem: 6331 sayılı İş Sağlığı ve Güvenliği Kanunu (İSGK). İş, Güç Endüstri İlişkileri ve İnsan Kaynakları Dergisi, 15, 17-41.

Mohamed, S. (2002). Safety climate in construction site environments. Journal of Construction Engineering and Management, 128, 375-384.

Mutlu, N. G. ve Altuntaş, S. (2017). Türkiye'de 1974-2016 yıllarında iş sağllğı ve güvenliği alanında yapılan lisansüstü tezlerin profili. Karaelmas Fen ve Mühendislik Dergisi, 7(2), 509-535.

Nahrgang, J. D., Morgeson, F. P. ve Hofmann, D. A. (2011). Safety at work: A meta-analytic investigation of the link between job demands, job resources, burnout, engagement, and safety outcomes. Journal of Applied Psychology, 96(1), 71-94. doi: 10.1037/a0021484

Neal, A. ve Griffin, M. A. (2006). A study of the lagged relationships among safety climate, safety motivation, safety behavior, and accidents at the individual and group levels. Journal of Applied Psychology, 91, 946-953.

Neal, A., Griffin, M. A. ve Hart, P. M. (2000). The impact of organizational climate on safety climate and individual behavior. Safety Science, 34, 99-109.

Öz, E. (2005). Ege Bölgesi’nde meydana gelen traktör kazalarının tarımsal iş güvenliği açısından değerlendirilmesi. Ege Üniversitesi Ziraat Fakültesi Dergisi, 42, 191-202.

Özk1lıç, Ö. (2005). İs să̆lı̆̆ ve güvenliği, yönetim sistemleri ve risk değerlendirme metodolojileri. İstanbul: Türkiye İşveren Sendikaları Konfederasyonu Yayınları.

Popper, K. (1959). The logic of scientific discover. London: Hutchinson

Probst, T. M. ve Estrada, A. X. (2010). Accident under-reporting among employees: Testing the moderating influence of psychological safety climate and supervisor enforcement of safety practices. Accident Analysis \& Prevention, 42(5), 1438-1444.

Rikhardsson, P. M. ve Impgaard, M. (2004). Corporate cost of occupational accidents: An activitybased analysis. Accident Analysis \& Prevention, 36(2), 173-182.

Sheikhtaheri, A. (2014). Near misses and their importance for improving patient safety. Iranian journal of public health, 43, 853-854.

Şen, H. ve Çınar, H. (2017). Mobilya ürün yaşam döngüsünde iş sağliği ve güvenliği analizi. Mühendislik Bilimleri ve Tasarım Dergisi, 5, 235-246.

Türkkan, A. (2009). İşe bağlı kas-iskelet sistemi hastalıkları ve sosyoekonomik eşitsizlikler. Uludăg Üniversitesi Tıp Fakültesi Dergisi, 35, 101-106.

Uluslarası Çalışma Örgütü (2017). World Statistics. Erişim adresi: https://www.ilo.org

Weil, D. (2001). Valuing the economic consequences of work injury and illness: A comparison of methods and findings. American Journal of Industrial Medicine, 40(4), 418-437.

Yaşar, S., İnal, S., Yaşar, Ö., ve Kaya, S. (2015). Geçmişten günümüze büyük maden kazaları. Bilimsel Madencilik Dergisi, 54, 33-43. 
Yeşildal, N. (2005). Sağlık hizmetlerinde iş kazaları ve şiddetin değerlendirilmesi. TSK Koruyucu Hekimlik Bülteni, 4, 280-302.

Zedeck, S., ve Mosier, K. L. (1990). Work in the family and employing organization. American Psychologist, 45(2), 240-251.

Zohar, D. (2000). A group-level model of safety climate: Testing the effect of group climate on microaccidents in manufacturing jobs. Journal of Applied Psychology, 85, 587-596. 
